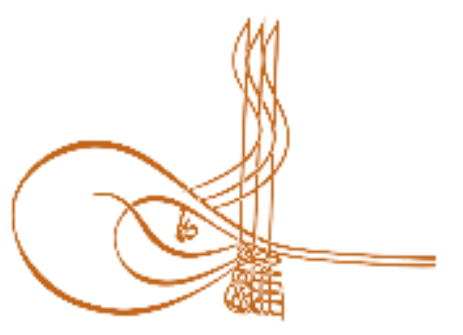

www.turkishstudies.net/turkishstudies
Turkish Studies

eISSN: $1308-2140$

Research Article / Araştırma Makalesi

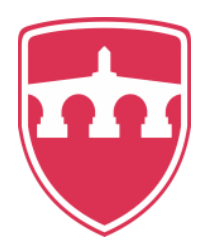

INTERNATIONAL

BALKAN

UNIVERSITY

Sponsored by IBU

\title{
Osmanlı Devleti'nde Kadınların Toprak ile İlgili Karşılaştığı Hukuki Sorunlar ve Divan-ı Hümayun'a Başvuruları (Ahkâm Kayıtlarından Örnekler)
}

\author{
Legal Problems Women Faced With Respect to Land in the Ottoman Empire and Women's \\ Applications to the Divan-i Humayun (Examples from the Ahkam Registers)
}

\author{
Çiğdem Kavak Çeken*
}

\begin{abstract}
Ottoman women, just like men, applied to the legal authorities of the state when they were subjected to injustice. They expressed their situations verbally in person or through their attorneys in the court wherein they took part as a defendant or plaintiff. In this process, women first sought their rights in the Sharia courts, and if they could not get the result they wanted, they wrote petitions and applied to the Divan-1 Humayun (Imperial Council of Ottoman). After making the fair copies of the draft decrees taken at the end of Divan-1 Humayun meetings, they were briefly written in certain books in the date order. One of the most important of these book series that are called Divan-1 Humayun Registers is the Ahkâm Books which covers complaints classified by their regions. In this study, a total of 202 decree records obtained from Ahkam Books, which were kept in the 19th century in the province of Istanbul, about the applications filed by women with respect to agricultural activities have been evaluated in terms of the subject of complaints in their contents in order to find out the major problems the women experienced regarding land that led them to apply to the Divan-1 Humayun. When these records containing the decrees made on women's applications are classified in terms of their subject, the primary reason for the applications of women, similar to all other records, was to stop unjust interventions by the shareholders, relatives or other residents of the area in their properties such as enfeoffed land, farms, farmlands, lots, pastures, meadows, vineyards, gardens, or orchards. In addition to this, the high number of applications filed due to the problems experienced related to descent is also remarkable (there are 60 records regarding the "descent of demesne", and 27 records regarding the "descent of property, vineyard, garden, and farmland"). Also frequently seen among these records are the applications made by women because the lands descended to them were attempted to be transferred to others by the "sahib-i arz" (owner of the land on behalf the state) in order to get surplus tax. It was also observed that multiple records were kept based on certain disputes. Some sample records related to intervention and descent have been evaluated as the primary sources showing the causes of the disputes that led women to apply to the Divan-1 Humayun and the resolutions developed in return.
\end{abstract}

\footnotetext{
* Arş. Gör. Dr., Dicle Üniversitesi, Hukuk Fakültesi, Maliye ve Ekonomi Bölümü Res. Asst. Dr., Dicle University, Faculty of Law, Department of Finance and Economics ORCID 0000-0001-8071-5724 cceken2016@gmail.com

Cite as/ Atıf: Kavak Çeken, Ç. (2020). Osmanlı Devleti'nde kadınların toprak ile ilgili karşılaştığı hukuki sorunlar ve Divan-1 Hümayun'a başvuruları (ahkâm kayıtlarından örnekler), Turkish Studies, 15(1), 327-344 https://dx.doi.org/10.29228/TurkishStudies.40201

Received/Geliş: 17 December/Aralık 2019

Accepted/Kabul: 25 February/Şubat 2020

Copyright $\mathbb{C}$ MDE, Turkey

Checked by plagiarism software Published/Yayın: 29 February/Şubat 2020 CC BY-NC 4.0
} 
Structured Abstract: In the Ottoman Empire, when individuals were subjected to injustice, they applied to the legal representatives of the state. In this process, they first sought their rights in the religious courts called Şer'iyye and, if they could not get the result they wanted, they applied to the Imperial Court called Divan-1 Hümayun by writing petitions. In the Ottoman judicial system, the courts are religious courts and Divan-1 Hümayun is their superior. In fact, the Divan-1 Hümayun is the special advisory body of the sovereign, in which state affairs are discussed on behalf of the sultan, the head of state, that is, decisions are made on his behalf and he is assisted in his decision making. Divân-1 Hümayun is the highest appellate authority in judicial aspect. Although there was no direct appeal procedure in the Ottoman Empire, those who were not satisfied with the outcome of a case could apply to the Divan-1 Hümayun, or the Divan-1 Hümayun could reconsider and render a verdict on the case. The right to make a complaint in the Ottoman Empire was not bound to any condition. Therefore, everyone had the right to make a complaint to the Court whether they were dhimmi-muslim or rayah-soldier. In the provisions sent to the administrative superiors of the region, it was warned that the complaints of the people to the Court should not be prevented and the public should not be offended. Those who wished to apply to the Divan-1 Hümayun were able to apply by themselves or through their representatives by writing petitions.

Ottoman women, like men, applied to the legal representatives of the state when they were exposed to injustice. Although Divan-1 Hümayun is in Istanbul, sometimes women expressed their verbal status either personally or through their representatives in the court where they applied as a defendant or plaintiff setting out to troublesome journeys from the furthest corners of the empire to present their cases. The conclusions of the decisions taken at the end of the Divan-1 Hümayun meetings were cleared and recorded as a summary in certain books in order of date. One of the most important of these series of books called Divan-1 Hümayun Registers is the court books called Ahkâm Notebooks containing the complaints classified according to regions. In this study, 202 records in the Ahkâm Notebooks of the province of Istanbul, covering applications related to agricultural activities by women in the 19th century (1800-1873) were discussed.

In the Ottoman Empire, women were not allowed to own land until the 16th century. However, not only the landownership, but other properties that women owned by inheritance were also wanted to be taken away from women yet it was tried to be prevented by the decisions of the Divan-1 Hümayun. Among the ways in which women can own property, securities and real estate inherited from the family take up an important place. Mehir and alimony, which are economic rights obtained by marriage, also enabled women to get ownership. Women owned the property of vineyards, gardens, fields, farms, mills, etc. in rural areas, and business premises such as shops, commercial enterprises, weaving workshops, etc. in addition to houses in the cities. Women were given the right to process the land on behalf of their deceased husbands in exchange for the deed. With these changing provisions on land saving, it was aimed to prevent the decrease of production in an agricultural society such as the Ottoman Empire, not to leave the land empty and to reduce the tax revenues. Although the right to save land was granted to women through legal changes after the second half of the 16th century, there were men who still objected to women's rights on the basis of old practices.

When the Ahkâm court records were evaluated, it was seen that the women also applied to the Divan1 Hümayun with their complaints in accordance with the other studies conducted by examining the archive documents. The fact that Divan-1 Hümayun was located in Istanbul and thus provided easier access was an important element in terms of the relatively higher number of records found in Istanbul Ahkâm Notebooks. There are also plenty of examples where complaints were made by themselves, not through a representative. This indicates that women also wanted to defend and articulate their rights on their own. The records in the archive documents show that women's complaints were usually related to a man's assault towards women's immovable property, violation of property and inheritance rights by a male family member such as husband, brother, nephew; or or a man living in that settlement outside the family. It was seen that the decisions taken emphasized that the allegations should be investigated and the law should be acted upon.

Based on these complaint records, when the issues for which women applied to Divan-1 Hümayun more often due to problems related to the land are evaluated, the most common reason for applications was the prevention of unfair interference of shareholders, relatives or residents of the region as with all other applications made by women regarding land issues. Applications made on this basis constitute approximately $72 \%$ of women's applications. Among 202 Ahkâm court records that women applied for, 77 was due to the intervention in grooming, property farms, fields and lands, 21 due to the intervention in forages, pastures, grasslands, and 32 due to the intervention of vineyards, gardens and orchards of their own property.

Turkish Studies, 15(1) 
After the intervention, the most common problems were seen to be related to descended inheritance, which makes up approximately $43 \%$ of the applications made by women. Among these records, there are 60 records of descended inheritance of miri soil, reeds and cane, and 27 records of descended inheritance of property, vineyard, garden and field.

In addition, there are 11 other records of applications that can be evaluated under the headings such as "sale of property farm, field, vineyard and garden (10 records), timar and sanitation of land (8 records), excessive tax demand and collection (5 records), mill intervention (4 records), crop intervention collected as tax (2 records), timar stock disagreements ( 3 records)" and different issues that cannot be evaluated under these headings. While specifying the number of records according to the reason for the application, the records containing more than one application reason are added to the number of records in each subject heading.

Keywords: Ottoman, Law, Women's Complaints, Ahkam (Verdict), Istanbul.

Öz: Osmanlı kadınları tıpkı erkekler gibi haksızlığa maruz kaldıklarında devletin hukuki temsilcilerine başvurmuşlardır. Davalı ve davacı olarak yer aldıkları mahkemede şahsen ya da vekilleri vasıtasıyla sözlü olarak durumlarını ifade etmişlerdir. Bu süreçte kadınlar haklarını öncelikle şer'iyye mahkemelerinde aramışlar, istedikleri sonucu alamazlarsa şikâyet dilekçeleri yazarak Divan-1 Hümayun'a başvurmuşlardır. Divan-1 Hümayun görüşmeleri sonunda alınan kararların müsveddeleri temize çekilerek belirli defterlere tarih sırasına göre özet olarak kaydedilmiştir. Divan-1 Hümayun Sicilleri adı verilen bu defter serilerinin en önemlilerinden biri de bölgelere göre sınıflandırılmış olan şikâyetleri içeren Ahkâm Defterleridir. Bu çalışmada İstanbul eyaletine ait, 19. yüzyılda tutulmuş Ahkâm Defterleri içinde yer alan, tarımsal faaliyetlerle ilgili kadınlar tarafından yapılan başvuruları içeren 202 hüküm kaydı, içerdikleri şikâyet konuları açısından değerlendirilerek, kadınların toprak ile ilgili daha çok hangi konularda yaşadıkları sorunlardan dolayı Divan-1 Hümayun'a başvurdukları tespit edilmeye çalışılmıştır. Kadınların başvuruları üzerine alınan kararları içeren bu kayıtlar konu bakımından sınıflandırıldığında, kendilerine ait olan tımar, mülk çiftlik, tarla ve arazilere, mera, yaylak, kışlak, otlak, çayır, bağ, bahçe ve bostana, hissedarların, akrabaların veya bölge sakinlerinden bir kimsenin haksız müdahalesinin engellenmesi amacıyla yapılan başvurular, tüm kayıtlarda olduğu gibi kadınların başvuru gerekçeleri içinde de en çok karşılaşılan başvuru nedenidir. Bunun yanısıra mirasen intikalde yaşanan sorunlardan dolayı yapılan başvuruların yüksekliği de dikkat çekmektedir ("miri toprağın, sazlık ve kamışlığın mirasen intikali” ile ilgili 60, "mülk, bağ, bahçe ve tarlanın mirasen intikali” ile ilgili 27 kayıt mevcuttur). Bu kayıtlar içinde kadınların kendilerine mirasen intikal eden topraklarının, sahibi arz tarafından fazladan vergi almak için başkasına verilmek istenmesi nedeniyle yaptıkları başvurulara da sık rastlanmaktadır. Bazı anlaşmazlıklara istinaden birden fazla kayıt tutulduğu da görülmüştür. Müdahale ve mirasen intikal ile ilgili bazı örnek kayıtlar, kadınların Divan-ı Hümayun'a başvurmalarına neden olan anlaşmazlıkları ve bu başvurulara istinaden geliştirilen çözümü gösteren birincil kaynak olması bakımından değerlendirilmiştir.

Anahtar Kelimeler: Osmanlı, Hukuk, Kadınların Şikâyetleri, Ahkâm, İstanbul.

\section{Giriş}

Osmanlı müesseselerinin mahiyeti ve hukuk kurallarının uygulanma biçimini göstermesi bakımından arşiv belgeleri 1şık tutucu birer kaynaktır. Divan-1 Hümayun'da tutulan mühimme defterleri, şikâyetlerin işlendiği ahkâm ve şikâyet defterleri, arazi kayıtlarının tutulduğu tapu tahrir defterleri, çeşitli fermanlar ve resmi makamların yazışmaları, hukukun devirlere göre uygulamalarını, zaman içinde gelişen hukuk algısını gösteren önemli kaynaklardır (Ekinci, 2012: 9495).

Osmanlı hukuku esas itibariyle İslam Hukukuna dayanır. Dolayısıyla şer'i hukukun hükümleri Osmanlı hukukunun da esas unsurlarını teșkil eder. Osmanlı hukukunun karakteristiğini teşkil eden bir de örfi hukuk vardır ki şer'i hukukun boşluk bıraktığı alanlarda hukuka aykırı olmamak kaydıyla hükümdar tarafından kanunnamelerle meydana getirilen hukuktur (Ekinci, 2014: $54)$. 
Osmanlı'da yarg1 görevi iki boyutludur: Bir yönü kişiler arasındaki anlaşmazlıkları çözümlemektir ki bu yönüyle kadı efendi bir yargıçtır. Diğer yönü ise kamu düzeni ile ilgilidir ve bu yönüyle de kadılar geniş yetkilere sahiptir. Osmanlı yarg1 sisteminde mahkemeler şer'i mahkemelerdir ve bunun bir üst kurulu ise Divan-1 Hümayun'dur. Divan-1 Hümayun aslında, devlet işlerinin devlet reisi olan padişah adına görüşüldüğü, yani onun adına karar alınan bir bakıma hükümdarın özel danışma organıdır. Divan-1 Hümayun adli yönden de en yüksek temyiz merciidir. Osmanlı Devleti içerisinde aslında doğrudan bir temyiz usulü olmamakla birlikte bir davadan çıkan sonuçtan hoşnut olmayanlar, Divan-1 Hümayun' a başvurabilmişler ya da Divan-1 Hümayun istediği davayı tekrar görüşüp karara bağlayabilmiştir. Divan'ın temyiz mercii olarak yüklendiği görevler kazaskerlerce yürütülmüştür. Onlar şikâyet dinleme ve davaya bakma işlemini kendi dairelerinde görmüşlerdir (Özgişi, 2014: 52-54).

Divan-1 Hümayun ve yerel kadı mahkemeleri, şeriat ve din dışı hukuk (kanun, örf) uygulamasını bütünleştirmiştir. Böylelikle her birinin elinde tuttuğu hukuk alanında herhangi bir çatışma olmamakta ve yerel kadı mahkemelerinin işlevi Divan-1 Hümayun tarafindan tamamlanmaktadır. Ayrıca Divan-1 Hümayun, yüksek siyasal otoriteyle yakınlığı daha fazla olduğundan halk arasında da meşruluk sağlayıp sultanın adaletini dağıtmaktadır. Başlangıçta Divan1 Hümayun idari suiistimallerin düzeltilmesiyle sınırlı ve yalnızca kendi toplumsal ve iktisadi statülerini daha iyi bir duruma getirmeye çalışan devlet görevlilerine ait bir alan iken 17. yüzyılın ikinci yarısından başlayarak başvuru hakkı reayaya da, vergi ödeyen tebaaya da tanınmıştır. $\mathrm{Bu}$ durum şikâyet deftrerleri adı verilen 17. yüzyılın ikinci yarısından 19. yüzyıl başına kadar uzanan dönemi kapsayan yoğun Osmanlı kayıtlarına yansımıştır. 18. yüzyıldan önce imparatorluğun verdiği hükümler "ahkam defterleri" ne kaydedilmekte olup bu kayıtların çoğu askeri-idari sınıfın mensuplarınca yapılan başvurulara verilen yanıtlardır. Özetle 17. yüzyılın ikinci yarısında Divan-1 Hümayun'a başvurma geleneği daha kapsayıcı olmuş, aralarında eşit ölçüde adalet arama olanağ verilen milletlerin ve kadınların da bulunduğu vergi ödeyen tebaayı(reayayı) kapsamaya başlamıştır. Bu durum 1839 Tanzimat reformlarından yüz yılı aşkın bir süre önce Osmanlı yönetiminde sivil toplumun artan önemini göstermesi bakımından önemli bir gelişme olarak nitelendirilmektedir (Zarınebaf- Shahr, 2000: 243).

Osmanlı Devleti'nde şikâyette bulunma hakkı herhangi bir şarta bağlanmamıştır. Dolayısıyla zımmi-müslüman ya da reaya-askeri, herkesin Divan'a şikâyette bulunma hakkı vardır. Konuyla ilgili bölgenin idari amirlerine gönderilen hükümlerde, ahalinin Divan'a olan şikâyetlerinin engellenmemesi ve halkın bu konuda rencide edilmemesi gerektiği ihtar edilmiştir. Divan-1 Hümayun'a başvurmak isteyenler dilekçe vererek, kendileri veya vekilleri aracıllğıyla başvurabilmişlerdir (Gümrükçüoğlu, 2012: 179).

\section{Osmanlı Devleti'nde Kadınların Hukuki Haklarını Kullanımı}

Osmanlı'da hukuki düzenlemeler, mülkiyet hakları ve hukuki işlem ehliyeti konusunda kadınlar ve erkekler için farklı kurallar belirlemediği gibi, bu hakların kullanışı aşamasında da kadınların evli ya da bekar olması bir fark yaratmamıştır. Bu çerçevede fiil ehliyetine sahip olan kadınlar her türlü hukuki işlemi yapabilmişler, alım-satım, hibe, mirasla intikal, vasiyet gibi yollarla menkul ve gayrimenkul malların maliki olabilmişlerdir. Ancak farklı yüzyıllar ve farklı coğrafyalardaki tereke kayıtları incelendiğinde belli bir düzeyde servete sahip kadın ve erkek murislerin terekelerinde kadınların aleyhine olacak şekilde önemli farklar ortaya çıkmaktadır. Ayrıca şer'iyye sicilleri ve arşiv belgeleri incelendiğinde kadınların mülkiyet haklarını korumak için ciddi bir hukuksal mücadele verdikleri görülmektedir. Bu bilgiler, Osmanlı kadınlarının hukuken sahip oldukları bir hakkı kullanmakta güçlük çektiklerini, sık sık mülkiyet haklarına müdahale edildiğini ve hukuki düzenlemelerle uygulama arasında derin bir fark olduğunu göstermektedir. Bu süreçte kadınlar haklarını öncelikle şer'iyye mahkemelerinde aramışlar, istedikleri sonucu alamazlarsa şikâyet dilekçeleri yazarak Divan-1 Hümayun'a başvurarak padişahın adaletine sığınmışlardır 
(Aky1lmaz, 2017:331). Divan-ı Hümayun görüșmeleri sonunda alınan kararların müsveddeleri temize çekilerek belirli defterlere tarih sırasına göre özet olarak kaydedilmiştir. Divan- Iümayun Sicilleri adı verilen bu defter serilerinin en önemlilerinden biri de bölgelere göre sınıflandırılmış olan şikâyetleri içeren ahkâm defterleridir (Aydın, 2015: 71-74).

Arşiv belgelerini referans alarak yerli ve yabancı bilim adamları tarafindan yapılan araştırmalar, Osmanlı kadını, toplumsal hayatı ve kadının imparatorluğun siyasi, ekonomik, sosyal ve kültürel hayatında oynadığı roller ile ilgili daha objektif bilgiler sunmuştur. Sicillerden hareketle yapılan Osmanlı kadınına dair çalışmalar, 1970'li yıllarda Jennings ile başlayıp 1980'li yılların başlarında Haim Gerber, Abraham Marcus, Afif Marsot, Judith Tucker ve Suraiya Faroqhi ile devam etmektedir. Bu çalışmalar Osmanlı kadınının sahip olduğu farklı tecrübeleri yansıtan ilk örneklerdir. Sicillerin sosyal ve ekonomik tarih açısından önemi ilk kez Ömer Lütfi Barkan ve Halil İnalcık tarafından dile getirilmiştir. Barkan ve İnalcık'ın çalışmaları doğrudan kadın ile ilgili olmamakla birlikte kadından da bahsetmektedirler (Argit, 2005: 577).

Türkiye'de şeriye sicilleri(mahkeme kayıtları) üzerine ilk akademik çalışmayı yapan yabancı araştırmacı Ronald Jennings, 17. yüzyıl Kayseri'sinde Anadolu kadınının hukuki konumunu, ahlaki değerleri, toplumsal hayat içinde kadınların rolünü ortaya koymaya çalışmıştır. Ronald Jennings'in bu araştırması, 1590-1630 yılları arasında, bir veya daha fazla kadının mahkemelik olduğu bin sekiz yüzü aşkın Kayseri mahkeme kayıtlarına dayanmaktadır. Jennings, Anadolu'da kadının o devirde sanılanın aksine tplumsal hayatın içinde olduğunu ortaya koymuştur. Jennings'in bulgularına göre 17. yüzyılda kadınlar mahkemeye başvurarak dava açabilmekte, ailelerinin erkeklerinden kocalarını ve kardeşlerini bile dava edebilmekte, bununla birlikte başkaları tarafından dava edilebilmektedirler (Jennings, 1975: 54).

Osmanlı toplumunda yaşayan kadınlar, evlenme, boşanma, mülk edinme (satış-alış), miras gibi olayları daha çok mahkemeye taşımışlardır. Kadınlar şer'i mahkemeleri erkekler kadar kullanmışlardır. Mahkemeler genellikle orta sınıf mensuplarınca, özellikle babalarını ve kocalannı yitirmeleri ve hane halkı arasında nüfuzlu ve zengin bir erkeğin bulunmaması sebebiyle güçlü akrabalık bağları bulunmayan kadınlar tarafından kullanılıyordu. Adli işlemlerde harç ödemek gerekliliği ve güvenilir tanık bulma zorluğu özellikle alt sınıf ya da kölelikten gelen kadınların mahkemeleri kullanmalarında dezavantaj yaratmakta olsa da kadı mahkemelerinin açıklığı, erişilirliği, çabukluğu ve tarafsızlığı gibi olumlu yönler de hakkın kullanımındaki avantajlı unusurlar olarak belirtilebilir (Akyüz, 2007: 77).

Arşiv belgelerinde bir kaza halkının şikâyetlerine rastlanıldığı gibi, kadın olsun erkek olsun bireysel şikâyetler de görülmektedir. Gerek toplu şikâyetler, gerekse bireysel olanlar bulundukları bölgenin kadısına giderek onun vasıtasıyla Divan'a arz gönderebilmişlerdir. Şikâyet eğer bir kaza halk1 tarafından yapılmışsa daha çok "mahzar gönderüp" veya "arz-1 mahzar" şeklinde ifadelendirilmiştir. Bunun dışında halktan bir şahsın doğrudan Divan'a şikâyette bulunması da mümkündür. Bu yapılan başvurular, "arz-1 hal edüp" veya "gelüp" ş̧eklinde kaleme alınırken, kadıların ve diğer görevlilerin şikâyetlerinin ise çoğunlukla "mektup gönderüp" şeklinde belirtildiği görülmektedir. Buna karşılık bireysel başvuruların yanında, ahalinin Divan'a gönderdiği şikâyetlerde de "arz-1 hal edüp" ifadesinin yer aldığ 1 görülmektedir (Gümrükçüoğlu, 2012:179-180). Arşiv belgelerinde yer alan kayıtlar kadınların şikâyetlerinin genellikle koca, erkek kardeş, yeğen gibi aile üyesi bir erkeğin ya da o yerleşim yerinde yaşayan aile dışından bir erkeğin taşınmaz mallarına yönelik tecavüzleri, mülkiyet ve miras haklarını ihlali ile ilgili olduğu görülmektedir (Akyılmaz, 2017: 325).

Zarinebaf-Shahr'ın aktardığı bilgilere göre şikâyet defterleri konusunda yapılan ilk araştırmalar 1680-1706 yılları arasında Divan-1 Hümayun'a yapılan başvuruların her yıl en az \%8'inin kadınlardan geldiği ve 18. yüzyıla gelindiğinde dilekçe verme eğiliminin arttığını göstermiştir. Özellikle İstanbul'da kadınlardan gelen dilekçe oranlarının \%8'den \%8,4‘e çıktığı 
görülmekle birlikte dilekçe verme oranları artışında kadınların payının çok değişmediği söylenebilir. İstanbul, hükümet merkezine ve Divan-1 Hümayun'a en yakın olduğundan en yüksek dilekçe oranını temsil etmektedir (Zarınebaf- Shahr, 2000:246). Yine Zarinebaf-Shahr'ın çalışmalarına göre 1675 yılında İstanbul'da kadınların mahkemeye sunduğu dilekçelerin \%39'unu miras anlaşmazlıklarının oluşturduğu görülmüştür. Bu çalışmada ayrıca İstanbul kadınları tarafindan verilen dilekçelerin \%34'ünün mallarla ilgili anlaşmazlıkları, \%16'sının ise borçların ödenmesi ile ilgili olanları konu aldığı tespit edilmiştir. Miras anlaşmazlıkları da eklendiğinde kadınların verdiği dilekçelerin \%89'unun mallar üzerindeki işlemlerle ilgili iktisadi konuların olduğu görülmüştür (ZarınebafShahr, 2000:248).

18. yüzy1l ile ilgili Esra Baş tarafından yapılan araştırmalarda da elde edilen sonuç bu araştırmaya benzerlik göstermiş olup, kadınların öncelikle miras davalarını ${ }^{1}$, bunu takip edecek şekilde sırasıyla mallarla ilgili davaları, borç davalarını, aile içinde bir ferdin (oğul-koca-baba) bir cinayete kurban gitmesi sonucu adli takibatın yapılarak suçluların cezalandırılmasını isteyen davalarını, aile fertlerinden birinin sürgün cezasının kaldırılmasını isteyen taleplerini, kendilerine yönelik kanuna aykırı hareketleri bulunan kişileri şikâyetlerini divana rahatıkla taşıdıkları tespit edilmiştir (Baş, 2006: 135-136).

Osmanlı Devleti'nde kadının hukuki statüsünü belirleyen konulardan birisi de miras hukukundaki konumudur. Osmanlı hukuk sisteminin ikili yapısı çerçevesinde her türlü mülk, menkul ve gayrimenkul mal mirasçılar arasında İslam Miras Hukuku hükümlerine göre paylaştırılmıştır. Ana kaynaklarda yer alan düzenlemelere göre kadınlar bazı durumlarda kendileriyle aynı konumda olan erkeklerin yarısı kadar mirastan pay alabilmişlerdir. Buna karşılık miri arazi, gayrisahih vakıflar, icareteynli vakıflar ve mukataalı vakıfların tasarruf hakkı ise örfi intikal hükümlerine göre gerçekleşmiştir. Örfi intikalde ise şer'i intikalin tersine zaman içinde cinsiyetler arası eşitlik temeline dayanan düzenlemeler yapılmıştır (Akyılmaz, 2007:473).

İslam hukukunda mirasın nasıl paylaşılacağı ayrıntılı olarak belirlenmiştir. Osmanlı hukuk sisteminde "tereke", "kassam", "metrukat", "muhallefat" defterlerinde tutulan miras kayıtları, şehir ve köylere ait beledi kassam ve askeri kassam defterlerinden oluşmaktadır. Kadı tarafından terekenin tespitinde vefat edenin sahip olduğu, dükkan, ev, bağ ve bahçe gibi gayri menkuller ayrıntılı olarak tespit edilmektedir. Mal ve mülklerin değeri belirlendikten sonra borçları çıkarılıp mirascılara dağıtılmaktadır. Şer'i miras hukukuna göre; mirastan yararlanma hakkına sahip yakın akrabalar şunlardır: Baba, cedd-i sahih (babanın babası), ana bir erkek kardeş (ah li ümm), anne, cedd-i sahiha (ananın anası, babanın anası), öz kız (sulbiyye), oğlun kızı(ibniyye), ana-baba bir kız kardeş, baba bir kı-kardeş, ana bir kız-kardeş, koca, karı (Barkan, 1966:20) .

Miras bölünürken erkek çocuklara kız çocukların ik katı verilmesi, İslam hukukunda kadının durumu iktisadi bakımdan teminat altına alınarak mirastan hiç bir şey almaya muhtaç bırakılmaması ve onun bütün ihtiyaçlarının kocası, babası, erkek kardeş ve amca gibi mahrem yakınlarının karşılamakla mükellef olması ve erkek mirasçıların mehr, nafaka sistemi içinde mükellefiyetlerinin ağırlığı nedeniyle bir dezavantaj gibi değerlendirilmemesi daha doğru olacaktır (Ekinci, 2012: 470). Bunun yanında mirastan yararlanacak olanların özel durumlarda paylaşımdan eşit yararlandığı da görülmektedir. Ayrıca kurulan vakıflar yoluyla bazı aileler kız ve erkek evlatlarının mirastan eşit yararlanmasını sağlamıştır (Can, 2008: 17).

\footnotetext{
${ }^{1}$ Edirne Havza'dan, Ayşe Hatun'un Divan'a arz ettiği dava, üzerinden onbeş yıl geçen bir davadır. Ayşe Hatun arzuhalinde, babası vefat ettiğinde kendisini küçük olduğunu, babasından kendisine miras kalan "kuleli" isimli çiftliği Ahmet Giray Han'ın zapt ettiğini, bu arada Ahmet Giray Han'ın da öldüğünü ve çiftliği şu anda Ahmet Giray Han'ın kız kardeşinin idare etiğini bildirerek, çiftliğin kendisine iadesini talep etmiştir. Davanın mahallinde görülmesi hükmü verilmiş, bu hükme göre bir görevli, dava mahalline inceleme yapmak üzere gönderilmiştir. Görevli dava sahibinin idareye malik olacak yaşta olduğunu bildirmektedir. Ayşe Hatun böylece on beş yıl gibi uzun bir sürenin ardından babasından miras kalan malına sahip olabilmiştir (Baş, 2006: 136).
} 
Kadınların mülkiyet sahibi olmasının yolları arasında aileden miras yoluyla intikal eden menkul ve gayrimenkuller büyük yer tutmuştur. Evlilik sonucunda nikah ile elde ettiği ekonomik haklardan mehir ve nafaka da mülk sahibi olmasını sağlamaktadır. 17. yüzyılda Konya Şer'iyye Sicilleri ile ilgili yapılan araştırmada kadınların evler, dükkanlar, bahçeler, tarlalar hatta değirmenler gibi gayrimenkullere sahip oldukları ${ }^{2}$, akrabalarına ya da başka kişilere borç para ve kredi verdikleri tespit edilmiştir (Gerber, 1980:233, Jenning, 1975:99). Kadınlar kendilerine ait olan mülkün başkaları tarafından haksız olarak kullanılması ya da zapt edilmesi durumunda mahkemeye başvurarak mülkleri üzerindeki haklarını korumaya çalışmışlardır. Kadınların kendi malları üzerinde istedikleri gibi tasarruf hakkı bulunması nedeniyle bazen koca, çocuk, damat, kardeş gibi yakın akrabalarına bazen de akrabası olmayan kişilere ev, bağ, dükkân, tarla, eşya, hayvan gibi mallar hibe etmişlerdir (Solak, 2016:999). İncelediğimiz 20 numaralı defterde yer alan 64 say1lı hüküm kaydındada ${ }^{3}$ kadınların miras yoluyla sahip oldukları bağ, bahçe, mal ve eşyalara müdahale ve bu müdahaleye engel olunması ile ilgili bir örnek görmekteyiz.

Osmanlı toplumunda tarım toprakların büyük bir bölümünü oluşturan miri arazinin mülkiyeti daima devlete ait olmakla birlikte intifa yani kullanım hakkı miras yoluyla mirasçılara geçebilmektedir. Mülk arazinin miras yoluyla intikali feraiz kaidelerine göre, miri arazinin intikali ise adi intikal suretiyle gerçekleşmekteydi (Kenanoğlu, 2006: 113). 1567 yılına kadar süren dönemde intikal hakkı sahibi yani bedel ödemeksizin araziyi iktisap hakkına sahip mirasçının bulunup bulunmadığı noktasında tartışmalı olup Cin ve Barkan gibi bir kısım hukukçular söz konusu devrede miri arazinin mutasarrıfın mirasçılarından hiçbirine bedelsiz olarak intikal etmeyip, ancak tapu misli ile erkek evlada tefviz edildiği, bazı hukukçular ise böyle bir dönemin hiç olmadığı ve erkek çocuğun başlangıçtan itibaren intikal hakkına sahip olduğu görüşünü ileri sürmüşlerdir. 1567 tarihinden önce çıkarılmış olan bazı kanunlar mutasarrıfın ölümü halinde arazinin erkek evlada bedelsiz olarak intikal ettiğini doğrularken yine bazı kanunnamelerden mutasarrıfin erkek çocuklarından da tapu bedelinin alındığı bir dönemin bulunduğu anlaşılmıştır. Dolayısıyla başlangıçta böyle bir uygulamanın var olduğu ve daha sonra erkek çocuklardan tapu bedeli alınması uygulamasının terk edildiği düşünülmektedir (Akyılmaz, 2007:490).

1567 yılından itibaren miri arazilerin mutasarrıfın erkek çocuklarına bedelsiz olarak intikal etmesi esası getirilmiştir (Kenanoğlu, 2005: 159). 1847'ye kadar devam eden bu dönemde muris erkekse intikal hakkı sahibi tek mirasçı erkek çocuktur. Kız çocuk ise ancak erkek çocuk yoksa tapu hakkı sahibi mirasçı olarak devreye girmekte ve tapu bedelini ödeyerek arazinin tasarruf hakkına sahip olabilmektedir. Ayrıca anne-baba bir erkek kardeşler kız kardeşlerinden, baba da anneden önce bu hakka sahip olabilmektedir. Muris kadın ise tüm bu sıralama geçersiz olmakta, sadece erkek çocuk, o da tapu bedelini ödemek suretiyle arazinin tasarruf hakkını kazanabilmektedir (Akyılmaz, 2007:490). 1847 yılında çıkarılan bir ferman ile mutasarrıfın vefat etmesi halinde kız çocuklara da erkek çocuklar gibi babalarından intikal eden miri araziyi bedelsiz talep etme hakkı tanınmıştır. Bu hak 1858 yılından itibaren çocukları yoksa anne ve babasına tanınmıştır (Kenanoğlu, 2006: 113).

1858 yılında yürürlüğe konulan Arazi Kanunnamesi'nin 54, 55 ve 56. maddeleri miri arazinin miras yoluyla intikalini düzenlemiştir. 54. madde hükmüne göre miri arazinin mutasarrıfının ya da mutasarrıflardan birinin vefat etmesi durumunda arazi erkek ve kız çocuklarına eşit olarak ve

\footnotetext{
216 numara Mühimme defterinde yer alan 1577 yılına ait bir kayıtta, İstanbul kadısına yazılan hükümde “ kızlara dükkan ve mahzen virilmeye" deyu mütevellilere ahkam-1 şerife virilmektle hal-i hayatlarında mameleklerin dekakin ve mehazine virenler vefat eyledikde yetimeleri şiddet-i ihtiyaçla muhtaç ve zelie oldukların bildürib kızlarına dahi verilmek babında istid2ay-1 inayet itdiklerinde 978 Cemaziye'l-ulasının sekizinci gününde kızlaırna dahi virilmek içün hükm-i hümayun virildüğin bildirüb" (Barkan, 1966:157).

3 "Gekbuze Nahiyesine bağlı Hereke Köyü’nden Emine ve Emetullâh adlı kadınlar gelip babaları Hüseyin'in 1233 senesinde öldügünü belirtmişlerdir. Aynı köydeki babalarına ait ve sınırları belli olan bağ, bahçe, mal ve eşyalar torunu Selim'e intikal etmiştir. Adı geçen kadınların kendi hisselerine düşen mallara Selim'in kanaatsiz bir şekilde müdahale ettiğinden bahisle birçok zarara uğramaları konusunun incelenmesi istenmektedir. Yapılan inceleme sonunda emrim gereği bu hisselere Selim'in fuzuli müdahaleden men edilmesi, hisselerin sahiplerine verilmesi ve haklının hakkını iade edilmesi".
} 
bedelsiz şekilde intikal eder. Mutasarrıfın yalnızca erkek ya da yalnızca kız çocuğunun olması durumunda da arazi eşit ve bedelsiz olarak bunlara intikal eder. Eğer vefat eden mutasarrıfın eşi hamile ise arazinin intikali, doğuma kadar bekletilir. 55. maddeye mutasarrıfin erkek ya da kız çocuğu yok ise miri arazinin tasarruf hakkı babasına, babası yok ise annesine, 54. maddede yazılı şartlara göre intikal etmektedir (Şimşek, 2011: 85-86). Kadının yer tasasrruf etmesine bir başka yol da vefat edenin mirascısı oğlu yetişinceye kadar annesinin oğlunun yerinde ziraat yapabilmesidir (Can, 2008: 19).

Toprak tasarrufu ile ilgili değişen bu hükümlerde temel hedefler, Osmanlı Devleti gibi tarım toplumu olan bir devletin üretiminin azalmasına engel olmak, toprağı boş bırakmamak ve vergi gelirinin azalmasına engel olmaktır. Sipahiler daha fazla vergi almaya kalkışmamaları konusunda uyarılmıştır. Vefat eden bir kimsenin yerlerinin boş bırakılmayıp birisi tarafindan işlenip ziraat yapılması resm ve öşrünün alınabilmesi bakımından devletin bir vergi politikası olarak daima zorunlu görülmüştür. Kadının yer tasasrruf etmesine bir başka yol da vefat edenin mirascısı oğlu yetişinceye kadar annesinin oğlunun yerinde ziraat yapabilmesidir (Can, 2008: 18).

Hukuk kaynaklarına dayalı yapılan çalışmaların çoğu şer'iyye sicilleri üzerine kurulmuş olup ikinci sırada en çok kullanılan kaynak fetvalardır ve sicil üstüne yapılan çalışmaları tamamlayıcı niteliktedir. Bunun dışında ahkâm defterleri, şikâyet defterleri ve vakıf defterleri kadın ve hukuk iliş̧isini kurmak adına çalışmalarda kullanılmaktadır (Argıt, 2005:576). Bu çalışmada İstanbul eyaletine ait, 19. yüzyılda tutulmuş Ahkâm Defteri içinde yer alan, tarımsal faaliyetlerle ilgili kadınlar tarafindan yapılan başvuruları içeren 202 hüküm kaydı, içerdikleri şikâyet konuları açısından değerlendirilerek, kadınların toprak ile ilgili daha çok hangi konularda yaşadıkları sorunlardan dolayı Divan-1 Hümayun' a başvurdukları tespit edilmeye çalış1lmıştır.

1. Kadınların Toprak ile illgili Karşılaștığı Hukuki Sorunlar

Araştırmacılar, kadınların İslam hukukunun(şeriat) kendilerine tanıdığı payları gerçekten elde edip edemediklerini, erkek akrabalarının bu paylara gayri resmi olsa da el koyup koymadıklarını saptamak için miras kavgalarını incelemişlerdir. Tarıma dayalı bir toplumda taşınmaz malların yaşamsal önemi düşünüldüğünde kadınların ev ve bahçe sahibi olabilme derecesi de ilgi uyandırmıştır. Bazı kadınlar, hak iddialarına uyacak biçimde eyalet kanunnamelerinde değişiklik yapıldıktan sonra çiftlik mirasçısı olmuşlardır. İdari rollere erişim sağlayan kadınlar da incelenmiş yine tımar sahibi ve önemsenecek düzeyde vakıf yöneticisi kadınlara rastlanmıştır(Faroqhı, 2000: 7).

İstanbul Ahkâm Defterleri'nden ${ }^{4}$ kadınların toprak ile ilgili karşılaştıkları sorunlara istinaden seçilen hüküm kayıtları ${ }^{5}$ konuları bakımından değerlendirildiğinde bir kayıt içinde bazen birden fazla konunun geçtiği görülebilmektedir. Bu hükümler içerdikleri her konu içinde değerlendirilmiştir. İhtilaflar konularına göre sınıflandırılırken daha önce yayınlanmış olan İstanbul Ahkâm Defterleri: İstanbul Tarım Tarihi II ${ }^{6}$ kitabında yer alan konu tasnif sistemi temel alınmakla birlikte burada geçen başlıklar içinde değerlendirilemeyecek konular da ayrı bir başlık altında değerlendirilmiştir. İçerdikleri konulara göre hüküm kaydı sayıları aşağıdaki tabloda özetlenmiştir:

\footnotetext{
${ }^{4}$ İstanbul Ahkâm Defterleri (A.DVNS. AHK. İS.d), Miladi Takvime göre 1742-1910 yılları arasındaki kayıtları içeren 26 adet defterden oluşmaktadır. Bu defterlerde İstanbul merkezi ile Beyoğlu, Üsküdar, Adalar, Gebze, Beykoz, Kartal, Küçükçekmece, Şile, Galata, Edirne, Karamürsel, Kale-i Sultaniye, Çatalca, Silivri ve Bandırma kazalarına; Harameyn ve Evkâf Müfettişliği'ne ve Serbostaniyân makamlarına hitaben yazılan hükümler bulunmaktadır (Başbakanlık Osmanlı Arşiv Rehberi, İstanbul, 3. Baskı, 2010). Hükümler dipnot gösteriminde Başbakanlık Osmanlı Arşivi (BOA), Defter Numaras1/ Sayfa Numaras1/ Hüküm Numarası şeklinde kısaltılmıştır.

${ }^{5}$ Bu örnekler, Ahmet Kal'a koordinatörlüğünde derlenen İstanbul Külliyatı IV serisinin İstanbul Ahkâm Defterleri İstanbul Tarım Tarihi çalışmasının basılmamış 4 cildinde yer alan hükümlerden seçilmiştir.

${ }^{6}$ Ahmet Kal'a (Proje Yömeticisi), İstanbul Ahkam Defterleri: İstanbul Tartm Tarihi II (1757-1763), Yayın Haz. Kurulu: Ahmet Tabakoğlu v.dğr./ and others, (İstanbul: İstanbul Büyükşehir Belediyesi Kültür İşleri Daire Başkanlığı İstanbul Araştırmaları Merkezi, 1997), s. /pp. 9-13.
} 


\begin{tabular}{|l|c|}
\hline \multicolumn{1}{|c|}{ Hüküm Konusu } & Hüküm Kaydı Sayısı \\
\hline Tmar, mülk çiftlik, tarla ve arazilere müdahale & 77 \\
\hline Miri toprağın, sazlik ve kamışlığın mirasen intikali & 60 \\
\hline Mülk bağ, bahçe ve tarlanın mirasen intikali & 27 \\
\hline Mera, yaylak, kışlak, otlak, çayır vb. müdahale & 22 \\
\hline Bağ, bahçe ve bostana müdahale & 31 \\
\hline Tmar toprağı ferağ ve tefvizi, müdahale & 11 \\
\hline Fazla vergi talebi ve tahsili & 5 \\
\hline Tmar hissesi ihtilafları & 3 \\
\hline Mültezimin vergi tahsiline müdahale & 3 \\
\hline Vergi olarak toplanan mahsule müdahale & 2 \\
\hline Vergiye tabi olmayanlardan vergi tahsili & 2 \\
\hline Mülk çiftlik, tarla bağ ve bahçe satış1 & 2 \\
\hline Diğer & 11 \\
\hline
\end{tabular}

Kendilerine ait olan tımar, mülk çiftlik, tarla ve arazilere, mera, yaylak, kışlak, otlak, çayır, bağ, bahçe ve bostana, hissedarların, akrabaların veya bölge sakinlerinden bir kimsenin haksız müdahalesinin engellenmesi amacıyla yapılan başvurular (130), tüm kayıtlarda olduğu gibi kadınların başvuru gerekçeleri içinde de en yüksek orandadır.

Kadınların başvuruları üzerine alınan kararları içeren bu kayıtlar konu bakımından sinıflandırıldığında, mirasen intikalde yaşanan sorunlardan dolayı yapılan başvuruların yüksekliği de dikkat çekmektedir ("miri toprağın, sazlık ve kamışlığın mirasen intikali” ile ilgili 60, "mülk, bağ, bahçe ve tarlanın mirasen intikali" ile ilgili 27 kayıt mevcuttur). Bu kayıtlar içinde kadınların kendilerine mirasen intikal eden toprakların, sahibi arz tarafindan fazla vergi almak için başkasına verilmek istenmesi nedeniyle yaptıkları başvurulara sık rastlanmaktadır.

Kadınların müracaat eden konumda olduğu 202 kayıt içinde 60 kayıt "miri toprağın, sazlık ve kamışlığın mirasen intikali" konusunu içermektedir. Kayitların ilgili olduğu ihtilaflar, mirasen intikal ile birlikte satış, ferağ, tefviz, müdahale gibi konular da içermektedir:

- 31 kayıt "Miri toprağın, sazlık ve kamışlığın mirasen intikali” ile "Tımar, mülk çiftlik, tarla ve arazilere müdahale" ile ilgili iken,

- 26 Kayıt "Miri toprağın, sazlık ve kamışlığın mirasen intikali" ile ilgili olup bu konu ile ilgili şikâyet edilenler genellikle sahib-i arzdır.

- 3 Kayıt ise; "Miri toprağın, sazlık ve kamışlığın mirasen intikali”, ve tımar toprağın ferağ ve tefvizi" ile ilgilidir.

27 kayıt; Mülk bağ, bahçe ve tarlanın mirasen intikali ile ilgili olup yine konuların içeriğinde bununla birlikte mülk bağ, bahçe ve tarlanın mirasen intikali, satışı, müdahalesi gibi hususlar da bulunmaktadir:

- 14 kayıt, Mülk bağ, bahçe ve tarlanın mirasen intikali ve müdahalesi

- 8 kayıt; Mülk bağ, bahçe ve tarlanın mirasen intikali

- 4 kayıt; Mülk bağ, bahçe ve tarlanın mirasen intikali ile satışı

- 1 kayıt, Mülk bağ, bahçe ve tarlanın mirasen intikali, satışı ve müdahalesi, 


\section{Kadınların Divan-ı Hümayun'a Başvuruları (19. Yüzyılda Tutulmuş Ahkâm Kayıtlarından Örnekler)}

18 numaralı defterde, 411 sayılı hüküm kaydında yer alan ${ }^{7}$ başvuru şöyle özetlenebilir: "Yoros Nahiyesine bağlı Hasbetlü Köyü'nden Emine'nin mutasarrıf olduğu tarlalarda her sene ziraat yapıp ve öşür vergisini de arz sahibine verdiği halde aynı köyde bazı kimseler 1225 tarihinden beri kanuna aykırı olarak müdahale etmektedirler. Yapılan incelemede arazinin 3 seneden fazla boş bırakılmaması gerektiğinden bahisle, tarlaların adı geçene verilmiş olduğu, hiç boş bırakılmadığı, ziraat yapıp öşür vergisini de verdiği anlaşılmıştır. Bundan dolayı emr-i şerifim gereğince bu tarlaların şahsa verilmesi ve kanunsuz müdahalenin engellenmesi kararı".

Bu hüküm kaydında yer bilgisine istinaden nahiye ve köy ismi bilgileri verilmiş ve Emine isimli hatunun gelip başvuru yaptı̆ğ ibaresi kullanılmıştır. Emine hatun, ziraatını yapıp vergisini de verdiği halde arazisine müdahale edildiğini ve bu müdahalenin engellenmesini talep etmiştir. $\mathrm{Bu}$ başvuruya istinaden inceleme yapıldığı ve inceleme yapılırken iki temel kuralın vurgulandığını görmekteyiz. Bu da arazinin 3 seneden fazla boş bırakılamayacağ 1 ve vergisinin ödenmesi gerektiği, bu şartların ihlal edilmediği müddetçe haksız müdahale edilmemesi gerektiğidir.

19 numaralı defterde yer alan 106 sayılı hüküm kaydı ${ }^{8}$ şöyle özetlenebilir: "Ümmü Gülsüm'ün Midyeye bağlı Korfakulübe Köyü'ndeki mutasarrıfe olduğu hududu belli çiftlik toprağında ziraat yapıp her sene zabt ve ziraat yapıp, öşür vergisini vermekte ve dışarıdan kişilerin müdahalesi gerekmemektedir. Ancak aynı köyden Hasan adlı kişi buraya 1227 senesinden beri fuzuli yere müdahale ettiğinden bunun önlenmesi ve eksik olan arazinin kendisine iadesini istemektedir. Yapılan incelemede söz konusu yerlerin şeyhülislam tarafindan verilen fetva gereğince mahallinde görülüp eksik olan arazinin sahibine verilmesi ve müdahalenin engellenmesi kararı".

Bu hükümde de Ümmü Gülsüm isimli kadının yine gelerek başvuruda bulunduğu ibaresi bulunmakta ve ziraatini yapıp vergisini verdiği halde toprağına yabancı bir erkeğin müdahalesi olduğu ve bunun engellenmesi talebi yer almaktadır. Yapılan incelemede bu talep haklı görülmüş ve müdahalenin engellenmesi yönünde karar alınmıştır.

19 numaralı defterde $119^{9}$ sayılı bir diğer hüküm kaydında başvuru gerekçesi şöyle özetlenebilir: "Gekbuze Nahiyesi’nden Zehra adlı kadın gelip adı geçen nahiyedeki araziye

\footnotetext{
${ }^{7}$ BOA 18/207/411 Yoros nâhiyesine tabi` Hasbetlü(?) nâm karye sâkinelerinden Emine nâm hâtûn gelüp bunun karye-i mezbûre toprağında kâin mutasarrıfe oldığı ma 'lûmetü'l-hudûd tarlaları beher sene tarafindan zabt u zir'at ve öşr ü resmi sâhib-i arza edâ olınagelüp âharün alâkası yoğiken karye-i mezbûre sâkinlerinden ma'lûmu'l-ism kimesneler iki yüz yiğirmi beş senesinde hilâf-1 kãnûn fuzûlî zabt idüp gadr-1 küllî itdüklerin bildirüp kãnûn üzre amel olınup mezbûrun hilâf1 kãnûn fuzûlî zabt eyledükleri mârrü’z-zikr tarlaları kendüye alıvirilüp tarafından zabt u zir'at itdürilmek bâbında emr-i şerîfüm sudûrını istid‘â itmekden nâşî Dîvân-ı hümâyûnumdan kãnûn suâl olındukda bu makúle arâzî üç sene ale’t-tevâlî bilâ mâni' boz ve halî kalmayarak mutasarrıfı tarafından zabt u zira'at ve öşr ü resmi sâhib-i arza edâ olınur iken cânib-i âhardan zabt olınması hilâf-1 kãnûn olmağla kãnûn üzre amel olınmak bâbında(1815).

8 BOA 19/39/106 Ümmügülsüm nâm hâtûn gelüp bunun Midye’ye tâbi‘ Korfakulübe karyesi toprağında vâk1‘ mutasarrıfe oldığı ma'lûmetü’l-hudûd çiftliği arâzîsi beher sene tarafından zabt u zirâ'at ve öşr ü resmi sâhib-i arza edâ olınagelüp âhardan dahl olınmak îcâb itmez iken karye-i mezbûre sâkinlerinden Hasan nâm kimesne iki yüz yiğirmi yedi senesinden berü fuzûlî zabt u zirâ'at itmeğle şimdi mezbûrun ol yirlerde zirâ'at eylediği senelerün terettüb iden noksân arâzîsini taleb eyledükde hilâf-1 şer'-i şerîf virmekde te'allül ü muhâlefet ve gadr-1 küllî sevdâsında oldığın ve bu bâbda da'vâsına muvâfik cânib-i şeyhülislâmdan fetvâ-yı şerîfe virildiğin bildürüp mahallinde şer'le görilüp merkúmun fuzûlî zabt eylediği senelerün terettüb iden noksân arâzîsi kendüye alıvirilmek bâbında emr-i şerîfüm sudûrını istid‘â itmekden nâşî mahallinde şer'le görilmek bâbında(1816).

${ }^{9}$ BOA 19/44/119 Gekbuze nahiyesi sâkinelerinden Zehrâ nâm hâtûn gelüp arâzî tasarruf idenlerinden babası İshak nâm kimesne iki yüz yiğirmi sekiz senesinde fevt oldukda oğlı kalmayup nahiye-i mezbûre toprağında vâk1 ' mutasarrıf oldığ1 ma'lûmetü'l-hudûd tarlası kãnûn üzre tapuya müstahıkk ve hakk-1 tapu bunun oldığına binâen bîgaraz müslimânlarun takdîr eyledükleri resm-i tapu ile sâhib-i arzdan almağa tâlibe iken sâhib-i arz olan kimesne tama'-1 hâmından nâşi ziyâde resm-i tapu ile âhara virürüm diyü te'allül ü muhâlefet üzre oldığın ve bu bâbda da'vasına muvâfık cânib-i şeyhülislâmdan fetvây1 şerîfe virildiğün bildürüp kãnûn üzre amel olınup vech-i meşrûh üzre müstahıkk-1 tapu olan babası yirleri bîgaraz müslimânlarun takdîr eyledükleri resm-i tapu ile sâhib-i arzdan kendüye alıvirilmek bâbında emr-i şerîfüm sudûrını istid'a
} 
mutasarrıf olan babası İshak'ın 1228'de ölümüyle oğlu olmadığı için kanun gereği sınırı belli olan tarlanın kendisine verilmesini istemektedir. Arz sahibinin buraları resmi tapu ile başkasına vermek istediğinden dolayı şeyhülislamdan alınan fetva üzerine, emr-i şerifim ve divan-1 hümayun incelenmesi sonucu resmi tapu ile kanun gereği olarak adı geçen kişiye verilmesi emr-i şerifimdir. Eğer adı geçen kadın buraları almaktan imtina ederse sahib-i arza ferağ eylemesi gerektiği ve bunun da kanun uyarınca kayda alınması kararı".

Bu kayıtta Zehra isimli hatunun yine gelip başvuru yaptığ1 ve babasının ölümüyle oğlu olmadığı için kanun gereği kendisine verilmesi gereken tarlanın sahibi arz tarafından başkasına verilmek istendiği bilgileri yer almıştır. Verilen kararda bu tarlanın başvuru yapan kadına verilmesi gerektiği, eğer kadın almak istemiyorsa o zaman ferağ edilmesi ve kanuna göre bu şekilde kayda alınması gerektiği belirtilmiştir. Bu başvuru, sahibi arzın kanuna uygun hareket etmediği durumlara örnek teşkil etmektedir.

19 numaralı defterde yer alan 175 numaralı hüküm kayd $1^{10}$; "Taşköprü Nahiyesi’nden Hanife'nin kocası İbrahim'in ölümü üzerine gelip nahiyedeki mutasarrıf ve sınırı belli olan arazinin oğlu Osman'a kanun gereği karşılıksız intikal etmiştir. Kocası buralarda ziraat yapıp her sene zabt ve ziraat yapıp, öşür vergilerini verir iken ölümü üzerine oğlu, kızı, baba bir er kardeşi ve kız kardeşi kalmamıştır. Adı geçenin kanun üzerine tapuya hak ve müstehak olduğunu beyan edip resmi tapu istemesi üzerine sahib-i arz başkasına veririm diyerek kanunsuzluk yaptığından kendisinin buralara müdahalesinin aykırı olmadığını beyan etmiştir. Bundan dolayı Hanife konunun incelenmesini talep etmektedir. Şeyhülislamdan fetva alınıp kanun üzerine hareket edilmesi gerektiğinden buralar, Hanife'nin oğlu Osman'a karşılıksız olarak resmi tapu ile verilmiştir. İbrahim'in her sene zabt ve ziraat yapıp, öşür vergilerini verir iken ölümü üzerine oğlu, kızı, baba bir er kardeşi ve kız kardeşi kalmamasından dolayı buraların sahib-i arzdan alınıp Osman'a verilmesi kararlaştırılmıştır. Eskiden olduğu gibi zabt ve ziraat yapıp vergilerini vermek şartıyla sahib-i arzın müdahaleden men edilmesi ve kanun gereği hareket edilmesi" olarak özetlenebilir.

20 numaralı defterde yer alan 64 sayılı hüküm kayd $1^{11}$ ise "Gekbuze Nahiyesine bağlı Hereke Köyü’nden Emine ve Emetullâh adlı kadınlar gelip babaları Hüseyin'in 1233 senesinde öldüğünü

itmekden nâşî ve Dîvân-1 hümâyûnumdan kãnûnı suâl olındukda bu makúle oğlı kalmayan müteveffânun yirleri bîgaraz müslimânlarun takdîr eyledükleri resm-i tapu ile kızına viiülmek ve ba 'de't-teklîf almakdan imtinâ' ider ise ol vaktde sâhibi arz tâlibine ferâğ eylemek kãnûn idüği tahrîr olınmağla kãnûn üzre amel olınmak bâbında (1816).

${ }^{10}$ BOA 19/65/175 Taşköpri nâhiyesi sâkinelerinden Hanîfe nâm hâtûn gelüp bunun zevci İbrâhîm nâm kimesne fevt oldukda nâhiye-i mezbûre toprağında vâkı' mutasarrıf oldığı ma 'lûmetü'l-hudûd tarlaları oğlı Osmân nâm kimesneye bi hasebi'l-kãnûn meccânen ba'de'l-intikãl mezbûr dahi zikr olınan yirleri beher sene zabt u zirâ'at ve öșr ü resmin sâhib-i arza edâ ider iken fevt oldukda oğlı ve kızı ve baba bir er karındaşı ve kız karındaşı kalmayup mârrü’l-beyân tarlalar kãnûn üzre tapuya müstahıkk ve hakk-1 tapu bunun oldığına binâen bu ol yirleri bîgaraz müslimânlarun takdîr eyledükleri resm-i tapu ile almağa tâlibe iken sâhib-i arz olan kimesne âhara virürüm diyü hilâf-1 kãnûn fuzûlî müdâhaleden hâlî olmadığın ve bu bâbda da'vâsına mutâbık fetvâ-yı şerîfe virildiğin bildürüp kãnûn üzre amel olınup vech-i meşrûh üzre olan oğlı yirleri bîgaraz müslimânlarun takdîr eyledükleri resm-i tapu ile sâhib-i arzdan kendüye alıvirilüp tarafindan zabt $u$ zirâ‘at itdürilmek bâbında emr-i şerîfüm sudûrını istid‘â itmekden nâşî Dîvân-ı hümâyûnumdan kãnûnı suâl olındukda münâza ‘un fîhâ olan yirlere mezbûrenün zevci mutasarrıfiken fevt oldukda ol yirler oğlı merkúm Osmân'a bi hasebi’l-kãnûn meccânen ba'de'l-intikãl mezbûr dahi ol yirleri beher sene zabt u zirâ'at ve öşr ü resmin sâhib-i arza edâ ider iken fevt oldukda oğlı kızı ve baba bir er karındaşı kalmayup mârrü'l-beyân yirler tapuya müstahıkk ve hakk-1 tapu vâlidesi mezbûrenün oldığına binâen zikr olınan yirler bîgaraz müslimânlarun takdîr eyledükleri resm-i tapu ile mezbûreye teklîf olındukda almakdan ibâ vü imtinâ‘ itmeğle sâhib-i arz âhara virürüm diyü müdâhale ider olmayup fí'l-vâk1' almağa tâlibe iken sâhib-i arz olan kimesne âhara virürüm diyü fuzûlî müdâhale eylediği vâk1' ise vech-i meşrûh üzre olan oğlı yirleri bîgaraz müslimânlarun takdîr eyledükleri resm-i tapu ile sâhib-i arzdan alıvirilüp tarafından zabt u zirâ'at itdürilmek içün emr-i şerîfüm i'tâs1 muvâfık-1 kãnûn idüği tahrîr olınmağla kãnûn üzre amel olınmak bâbında(1817).

${ }^{11}$ BOA 20/22/64 Gekbuze nâhiyesine tâbi` Hereke karyesi sâkinelerinden Emine ve Emetullâh nâm hâtûnlar gelüp mezbûre Emine' nün zevci ve mezbûre Emetullâh'un babası Hüseyin nâm kimesne iki yüz otuz üç senesinde fevt oldukda karye-i mezbûre toprağında mutasarrıf oldığı ma'lûmu'l-hudûd mülk menzil ve bâğ ve bâğçeleriyle emvâl ve eşyası bi'lirsi'ş-şer'î bunlar ile karye-i mezbûre sâkinlerinden oğl1 Alî'nün oğlı Selîm nâm kimesneye intikãl itmişiken merkúm Selîm kendü hisse-i irsiyyesini ahza adem-i kanâ‘ at birle cümlesini hilâf-1 şer'-i şerîf fuzûlî zabt idüp gadr-1 küllî eylediğin ve bu bâbda da'vâsına muvâfık canib-i şeyhülislamdan fetvâ-yı şerîfeleri oldığın bildürüp mahallinde şer'le görilüp müteveffâ- 
belirtmişlerdir. Aynı köydeki babalarına ait ve sınırları belli olan bağ, bahçe, mal ve eşyalar torunu Selim'e intikal etmiştir. Adı geçen kadınların kendi hisselerine düşen mallara Selim'in kanaatsiz bir şekilde müdahale ettiğinden bahisle birçok zarara uğramaları konusunun incelenmesi istenmektedir. Yapılan inceleme sonunda emrim gereği bu hisselere Selim'in fuzuli müdahaleden men edilmesi, hisselerin sahiplerine verilmesi ve haklının hakkının iade edilmesi" olarak özetlenebilir.

20 numaralı defterde yer alan 265 sayılı bir diğer örnek hüküm kayd $1^{12}$ ise "Aşağıda adı geçen küçük çocuğu vasisi ....adlı kadın gelip küçük yaştaki oğlu Mehmet Şükri babasından intikal eden Marmara'daki sınırları belli olan tarlalara mutasarrıf iken ölmüştür. Erkek kardeşi olmadığından da buralar tapuya hakkı olan küçük kız kardeşi Şerife Ayşe'ye burada yaşaması şartıyla intikal etmiştir. Ancak sahib-i arz buraları vermek istemeyerek buralar benim malımdır ben zapt ederim diyerek müdahale etmekte ve tapu vermemektedir. Bu durumda adı geçenin kardeşi zarara uğramakta olduğundan buraların sahib-i arz tarafından Şerife Ayşe'ye verilmesi istenmektedir. Konun araştırılması sonucu kanun gereği sahib-i arzın buraları adı geçene ve annesine tapusunu vererek müdahaleden vazgeçmesine dair emri şerifim gereği Divan-1 Hümayundaki kayıtlar incelendiğinde; Mehmed Şükri'nin babasından kalan yerlere mutasarrıf iken vefat etmesi ile baba bir erkek kardeşi kalmadığından oralara kız kardeşi mutasarrıfe olacaktır. Ancak sahib-i arz buraları adı geçene vermek istememesinin engellenmesi ve kanun gereği Şerife Ayşe'nin vasisine iade edilmesi ve kanun üzere hareket edilmesi" olarak özetlenebilir.

20 numaralı defterde yer alan 418 numaralı kayı1 ${ }^{13}$ "Emine adlı kadın sarayıma arz gönderip Gekbuze'deki Parkazlık adlı mahalledeki tapu ile mutasarrıf olduğu tahminen 22,5 kile tohum ürün veren sınırı belli bir kıta tarlasının zabt ve ziraat yapıp, öşür vergilerini sahib-i arza verdiği halde bazı yabancı kimselerin kanunsuz olarak müdahale ettiğini belirtmiştir. İncelenen kanun üzerine mutasarrıf buraları 3 sene boş bıraktıysa elinden alınıp diğer kişilere verilmesinin, her sene ekti ise yine aynı kişiye verilmesinin ve diğer kişilerin müdahalesinin engellenmesinin uygun olacağı için yabancıların sahibi-arzdan bu araziyi adı geçen kadının araziyi 3 sene boş bırakmasından dolayı mı

y1 merkúmdan müntakıl merkúmun hilâf-1 şer‘-i şerîf fuzûlî zabt eylediği mârrü’z-zikr menzil ve bâğ ve bâğçe ve emvâl ve eşyâdan hisse-i irsiyyeleri kendülere alıvirilüp icrâ-yı șer` ve ihkãk-1 hakk olınmak bâbında emr-i şerîfüm sudûrını istid‘â itmeleriyle mahallinde şer'le görilmek bâbında (1820).

${ }^{12}$ BOA 20/92/265 Zikri atî sağïrenün ba hüccet-i şeriyye vasiyyesi (boş) nam hatun gelüp bunun oğl1 sabî Mehmed Şükrî [ba]basından müntakıl Marmara toprağında vakımalumetül-hudud tarlalara mutasarrıfiken fevt oldukda baba bir er karındaşı kalmayup tasarrufında olan yirleri tapuya müstahıkk ve hakk-1 tapu yurdı üzerinde sakine olmak şartıyla kız karındaşı sağïre Şerîfe Ayişe'nün oldığına binaen ol yirleri bîgaraz müslimanlarun takdîr eyledükleri resm-i tapu ile sağïrei mezbure içün sahib-i arzdan bil-vesaye almağa talibe iken sahib-i arz olan ol yirler benüm sarf-1 mahlulümdür ben zabt iderüm diyü hilaf-1 kanun tapu ile virmekden imtina idüp gadr-1 küllî eylediğin bildürüp kanun üzre amel olınup müteveffay1 mezburun karındaşı yirleri bîgaraz müslimanlarun takdîr eyledükleri resm-i tapu ile sahib-i arzdan sağïre-i mezbure içün bil-vesaye kendüye alıvirilüp tarafından zabt u ziraat itdürilmek babında emr-i şerîfüm sudurını istida itmekden naşî Dîvan1 hümayunumdan kanunı sual olındukda mezburenün oğlı sabî Mehmed Şükrî babasından müntakıl yirlere mutasarrıf iken fevt oldukda baba bir er karındaşı kalmayup tasarrufında olan yirleri tapuya müstahıkk ve hakk-1 tapu yurdı üzerinde sakine olmak şartıyla kız karındaşı sağïre-i merkume Şerîfe ayişe'nün olap bîgaraz müslimanlaran takdîr eyledükleri resm-i tapa ile validesi ve vasiyyesi mezbareye teklîf olındakda almakdan iba vü imtina itmeğle zabt ider olmayap fil-vakı ol yirleri sağire-i mezbare içün resm-i tapa ile sahib-i arzdan bil-vesaye almağa talibe iken sahib-i arz olan kimesne ol yirler benüm sarf-1 mahlalümdür ben zabt iderüm diyü hilaf-1 kanan tapa ile virmekden imtina eylediği vakı ise müteveffa karındaş1 yirleri bîgaraz müslimanlaran takdîr eyledükleri resm-i tapa ile sahib-i arzdan sağire-i mezbare içün vasiyyesi mezbareye alıvirilüp tarafından zabt a ziraat itdürilmek kanan idüği tahrîr olınmağla kanan üzre amel olınmak babında(1823).

${ }^{13}$ BOA 20/156/418 Emine nâm hâtûn Südde-i sa‘âdetüme arz-ı hâl idüp banan Gekbaze toprağında Parkazlık nâm mahallde kâin tapa temessükiyle matasarrıf oldığı tahmînen yiğirmi iki baçak keyl tohm istî‘âb ider ma'lûma'l-hadûd bir kıt'a tarlası tarafından zabt a zirâ'at ve öşr ü resmi sahib-i arza edâ olınagelüp âhardan dahl olınmak îcâb itmez iken ecânibden ba'zı kimesneler zikr olınan tarlaya hilâf-1 kãnûn fazûlî müdâhaleden hâlî olmadakların bildürüp kãnûn üzre amel olınmak bâbında emr-i şerîfüm sadûrını istid'â itmeğin imdi üç sene ale't-tevâlî bilâ mâni' boz ve hâlî kalan yirleri sahib-i arz resm-i tapa ile tâlibine virüp zabt a zirâ‘at itdürilmek kãnûn olmakdan nâşî eğer ol tarla merkúmenün tarafindan zirâ‘at itmeyüp üç sene ale’t-tevâlî bilâ mâni‘ boz ve hâlî bırağap kãnûn üzre müstahıkk-1 tapa olmış ve merkúmlar dahi ol tarlayı bozdan sahib-i arzdan resm-i tapa ile almışlar ise ber mûceb-i kãnûn müdâhaleleri yolında olap eğer böyle olmayap da ol tarla mezbûrenün tarafından beher sene zabt a zirâ‘at ve öşr ü resmi sahib-i arza edâ olınar iken ol vaktde merkúmlaran müdâhaleleri hilâf-1 kãnûn olacağına binâen ba bâbda kãnûn üzre amel olınmak bâbında(1825). 
aldığı yoksa her sene ziraat yapıp öşürünü verdiği halde mi elinden aldığı konusunun incelenip kanun üzerine hareket edilmesi" şeklinde özetlenebilir.

20 numaralı 597 sayılı hüküm kayd1 ${ }^{14}$ "Nazife adlı kadın gelip rikâb-1 hümayunuma gönderdiği dilekçe ile Şile'de mutasarrıfe olduğu üzüm bağına Şile halkından kardeşinin karısı Hadice'nin 1245 senesinden beri müdahale ettiğini ve ürünlerine el koyduğundan zarara uğradığını bildirmiştir. Hadice'nin buraya kanunsuz yere müdahale ettiği anlaşıldığından emr-i şerifim gereği bağ ve ürünlerin mahallinde görülerek Nazife'ye verilmesi" şeklinde özetlenebilir.

21 numaralı defterde yer alan 70 sayılı hüküm kayd1 ${ }^{15}$ "Ayşe Sıdıka adlı kadın gelip Küçükçekmece Kazasına bağlı Florya Köyü’ndeki tapulu ve senetli olarak mutasarrıfe olduğu sınırı belli bir kıta arazisine adı geçen köydeki isimleri belli bazı kimselerin kanunsuz yere müdahale ettiğinden bahisle bu kişilerin engellenmesi istemektedir. Kanun gereği mutasarrıflar buraları 3 sene arka arkaya boş bıraktıysa elinden alınıp diğer kişilere verilmesinin, her sene ekti ise yine aynı kişiye verilmesinin ve diğer kişilerin müdahalesinin engellenmesi gerektiğidir. Hal böyle iken o yerleri zabt eden ziraat yapmayıp da 3 sene mazaretsiz olarak boş bıraktıysa sahib-i arzdan alan kişilere değil, ziraat yapıp vergilerini veriyor ise hakkı olana yani adı geçen bayana iadesi ve bazı kişilerin müdahalesinin engellenmesi" şeklinde özetlenebilir.

21 numaral1 356 sayılı hüküm kayd116: "Silivri Kazasına bağlı Akviran Köyü’nden Fâtıma adlı kadın gelip aynı köydeki mutasarrife olduğu ve ziraat yapıp öşür vergisini verdiği sının belli olan tapulu ve senetli toprağından bahisle; yine aynı köyden Süleyman Kethüdanın buralara kanunsuz olarak mandıra açtığı ve kendisini zarara uğrattığını belirtilmiştir. Kanun gereğince tapu verilip, ziraat yapılan, vergileri verilen yerlere sonradan mandıra yapıp işletmek yasak olduğundan müdahalenin engellenmesi ve bu şekilde hareket edilmesi" olarak özetlenebilir.

22 numaralı 71 sayılı hüküm kayd ${ }^{17}$ : "Emine adlı kadına babası Mühürdaroğlu Mustafa'nın

\footnotetext{
${ }^{14}$ BOA 20/245/597 Nazîfe nâm hâtûn rikâb-ı hümâyûnama arz-ı hâl idüp banan Şile toprağında vâk1 ' bâ hüccet-i şer'iyye matasarrıf oldığı kürûmı mevcûd bir kıt'a mülk bâğında âharan alâkası olmayap dahl olınmak îcâb itmez iken Şile sâkinelerinden mezbûrenün karındaşınan zevcesi Hadîce nâm hâtûn bâğ-1 mezkûrı iki yüz kırk beş senesinde hilâf-1 şer'-i şerîf fazûlî zabt ve mahsûlüni ahz ile istihlâk idüp ol vechile gadr-1 küllî eylediğin bildirüp mahallinde şer'le görilüp mezbûran hilâf-1 șer'-i șerîf fazûlî zabt eyledüği bâğ-1 mezkûr ile mahsûl-i müstehliki kendüye alıvirilüp icrâ-y1 șer'-i șerîf ve ihkãk-1 hakk olınmak bâbında emr-i şerîfüm sadûrını istid'a itmekden nâşî mahallinde şer'le görilmek bâbında(1830).

${ }^{15}$ BOA 21/27/70 Âyişe Sıdîka nâm hâtûn gelüp banan Çekmece-i sağìr kazâsına tabi‘ Florya karyesi toprağında kâin tapalı ve temessükli matasarrıf oldığı ma'lûmetü'l-hadûd bir kıt'a arâzîsinde âharan alâkası olmayap dahl olınmak îcâb itmez iken karye-i mezbûre sâkinlerinden ma'lûma'l-ism kimesneler hilâf-1 kãnûn fazûlî müdahale ve zabt dâ‘iyyesinde oldakların inhâ ve kãnûn üzre amel olınap merkúmlaran hilâf-1 kãnûn ol vechile vâk1' olan müdâhaleleri men` a def olınmak bâbında emr-i şerîfüm sadûrını istid'â itmekden nâşî imdi mezbûre ol yirleri zabt ider iken zira'at itmeyüp üç sene ale’t-tevâlî bilâ mâni` boz ve halî koyap kãnûn üzre müstahıkk-1 tapa oldakda dahl iden merkúmlar bozdan sâhib-i arzdan resm-i tapa ile almışlar ise müdâhaleleri bi hasebi'l-kãnûn yolında olap eger böyle olmayap da fi'l-vâk1 ' mezbûre arâzî-i merkúmeye tapalı ve temessükli matasarrıf olarak beher sene tarafından zabt a zira 'at ve öşr ü resmin sâhib-i arza edâ olınagelür ise ol vaktde merkúmlaran müdâhaleleri bîvech ve hilâf-1 kãnûn olacağına binâen ba bâbda kãnûn üzre amel olınmak bâbında(1833).

${ }^{16}$ BOA 21/156/ 356 Silivri kazâsına tâbi‘ Akvîrân karyesi sâkinelerinden Fâtıma nâm hâtûn gelüp karye-i merkúm toprağında vak1 ' kadîmden tapa ile virilüp zabt ü zirâ'at ve öşr ü resmi alınagelen ma'lûmetü’l-hadûd yirlere tapalı ve temessükli matasarrıfe olap beher sene tarafından zabt ü zirâ‘at ve öşr ü resmin sâhib-i arza edâ olınagelüp âharan alâkası olmayap ve ba makúle kadîmî zirâ‘at olınap öşr ü resmi alınagelen yirler üzerine sonradan mandıra ihdâs olınmak hilâf-1 kãnûn iken karye-i mezbûr sâkinlerinden Süleymân Kethadâ nâm kimesne ol yirler üzerine hilâf-1 kãnûn mandıra ihdâs idüp gadr-1 küllî eylediğin inhâ ve ol bâbda emr-i şerîfüm sadûrını istid‘â itmekden nâşî Dîvân-i hümâyûnamdan kãnûnı saâl olındakda münâza $\square$ an fîhâ olan yirler kadîmî mandıra yiri olmayap fi'l-vâk1' kadîmden tapa ile virilüp zabt ü zirâ‘at ve öşr ü resmi alınagelen yirlerden olarak mezbûre ol yirlere tapalı ve temessükli matasarrıfe ise ba makúle kadîmî zirâ‘at olınap öşr ü resmi alınagelen yirler üzerine sonradan mandıra ihdâs olınmak hilâf-1 kãnûn olap men' a def'i mavâfik-1 kãnûn idüği tahrîr olınmağla kãnûn üzre amel olınmak bâbında(1838).

${ }^{17}$ BOA 22/38/71 Emine nâm hâtûnan babas1 Mühürdâroğl1 Mastafâ nâm kimesne bandan akdem fevt oldakda Gekbaze kazâsına tâbi“ Kahroli(?) karyesi toprağında vâkı‘ matasarrıf oldığı bir kıt $\square$ a çiftliği emlâkiyle bir bâb mülk ağılı bi’l-irsi'ş-şer‘î mezbûreye intikäl itmişiken karye-i mezbûre sâkinlerinden mezbûrenün dayısı el-Hâcc Ârif nâm kimesne çiftlik emlâkiyle mülk ağılını hilâf-1 şer'î17 şerîf fazûlî zabt idüp gadr-1 küllî eylediği beyânıyla mahallinde şer'le ra $\square$ yet
} 
ölümü üzerine Gekbuze Kazasına bağlı Kahroli(?) Köyü’nde mutasarrıf olduğu çiftlik ile bir odalı ağıl irsen intikal etmiştir. Ancak bu çiftlik ve ağıla aynı köyden dayısı el-Hâcc Arif' in haksız yere el koymuş, müdahale etmiş ve zarara uğratmıştır. Haklıya hakkını vermek babında emr-i şerifim gereğince bu konuyu yerinde incelenip haksızlık varsa giderilmek istenmektedir. Yerinde yapılan araştırma neticesinde özürsüz olarak 15 sene geçmediği halde el-Hacc Arif'in buralara fuzuli yere el koyduğu anlaşılmıştır. Söz konusu yerlerin sahibine iade edilmesi konusunda gerekli incelemeleri hakkıyla yapasınız" olarak özetlenebilir.

24 numaralı 156 sayılı hüküm kaydı ${ }^{18}$ : "Emetullâh adlı kadının Erdek Kazası'ndaki kayınvalidesinden intikal eden hüccet ile mutasarrıfe olduğu ağaçlı iki kıta bahçeyi kocası Salih'in İbrahim adlı kişiye usulsüz olarak sattı̆̆ından bahisle; adı geçen kadın burasını İbrahim'den istediğinde o da vermeyerek zarara uğramasına sebebiyet vermiş olduğu beyanıyla mahallinde araştırılması istenmektedir. Siz ki kaymakam, naip ve sairler olarak bu kişileri mahkemeye çağırarak yüzleştirme yapınız. Özürsüz olarak 15 sene geçmediği halde bu husus doğru ise haklının hakkını vermek babında karar verip bu kararı da kayıt altına alarak benim makamıma gönderesiniz" şeklinde özetlenebilir.

24 numaralı 227 sayılı hüküm kayd $1^{19}$ : "Nimeti adlı kadın; Kartal Kazasına bağlı Yayalar Köyü'ndeki tapu karşılığı mutasarrıf olduğu 10 kile ürünlü sınırı belli bir kıta tarlayı her sene ziraat

ve ihkäk-1 hakk olınmak bâbında emr-i şerîfüm sadûrını mezbûre ba def‘a bâ arz-1 hâl istid‘â itmekden nâşî mahallinde şer'le ra $\square$ yet olınmak fermânam olmağın imdi siz ki mûmâ ileyhimsiz ma'rifetinüz ile merkūmı mahallinde akd olınan meclise ihzâr ve mezbûre ile ber nehc-i şer'î hakkäniyyet vechile terâfa' -1 şer'-i şerîf iderek hasûs-1 mezbûr inhâ olındığ 1 üzre oldığı ve bilâ özr-i şer' on beş sene mürûr itmediği hâlde mezbûrenün babasından müntakıl merkūman hilâf-1 şer'-i şerîf fazûlî zabt eylediği emlâk-i mezkûresin ba‘de’s-sübût hükm idüp mezbûreye alıvirüp icrâ-yı şer'-i şerîf ve ihkäk-1 hakka mübâderet olınmak bâbında(1843).

${ }^{18}$ BOA 24/72/156 Emetallâh nam hâtûnan Erdek kazâsında kâin vâlidesinden intikãlen bâ hüccet-i şer'iyye mülkiyyet üzre matasarrıfe oldığg eşcârı mevcûd iki kıt'a bâğçesinde âharan alâkası yoğiken mezbûrenün zevci Sâlih nâm kimesne zikr olınan bâğçeleri hilâf-1 şer'-i şerîf fazûlî zabt ve İbrâhîm nâm kimesneye bey“ itmiş ve mezbûre bâğçe-i mezkûreleri zü'l-yedân-1 merkúmdan taleb eyledükde virmeyüp gadr dâ‘iyyesine düşmüş oldığı beyânıyla mahallinde şer'le ra'yet ve ihkãk-1 hakk olınmak bâbında emr-i şerîfüm sadûrı mezbûre Emetallâh tarafindan ba def'a bâ arz-1 hâl istid'â olınmış olmağla siz ki kãimmakãm ve nâib vesâir mûmâ ileyhimsiz ma'rifetinüz ile merkúm İbrâhîm'i mahallinde meclis-i memlekete ihzâr ve mezbûre ile bi'l-mavâcehe ber nehc-i şer‘î terâfa' iderek hasûs-1 mezbûr inhâ olındığı üzre oldığı ve bilâ özr-i şer‘î on beş sene geçmediği inde'ş-şer' ve'l-meclis tebeyyün ve tahakkak eylediği hâlde ba'de's-sübût ber maktezâ-y1 şer'-i enver icrâ-y1 şer'-i şerîf ve ihkãk-1 hakka mübâderet ve hasûs-1 mezbûr ilâ âhirihî dikkat ve keyfiyyetün kaydı bâlâsına şerh virilmek üzre der-bâr-1 şevket-karâr-1 mülûkâneme inhâ ve iş'ârına müsâra'at eylemenüz bâbında(1857).

${ }^{19}$ BOA 24/101/227 Mîrmîrân-1 kirâmamdan Kocaili sancağı matasarrıfi Vahîd Paşa dâme ikbâlehûya ve Kartal kazâs1 nâibine ve müdîr-i kazâ ve vücûh-1 memlekete hüküm:Ni'metî nâm hâtûnan Kartal kazâsına tâbi' Yayalar karyesi toprağında vâkı' mamûlün bih tapa senediyle matasarrıfe oldığı on keyl tohm istî‘âb ider malûmetü'l-hadûd bir kit'a tarlalarını zabt ve beher sene tarafından zirâ‘at ve öşri edâ olınagelür iken mezbûrenün zevci Mastafầ nâm kimesne mârrü’zzikr tarlayı hilâf-1 kãnûn fazûlî zabt ve Pendik karyesi sâkinlerinden ve tebe'a-i Devlet-i aliyyemden Zotri'ye bey' a ferâğ idüp gadr eylediği beyânıyla mübâşir ma'rifetiyle kãnûn üzre amel olınmak ve mümkin olmaz ise Der-sa'âdetüme ihzârı i'lâm kılınmak bâbında emr-i şerîfüm sadûrı mezbûre Ni‘metî tarafından ba def'a bâ arz-1 hâl istid'â olınmış ve Dîvân-1 hümâyûnam kaleminden kãnûnı saâl olındakda münâza'an fîhâ olan tarlaya mezbûre Ni 'metî bâ tapa matasarrıfe iken hakk1 tasarrafını rızâsı ve sâhib-i arz ma'rifetiyle merkúm Mastafâ'ya ferâğ a tefvîz itmiş ve yedine mamûlün bih sened virilmiş ise zabt eylemesi hasbe'l-kãnûn yolında olap eger böyle olmayap fi'l-hakïka mezbûre Ni'metî ol yirlere mamûlün bih tapa senediyle matasarrıfe olarak zabt ve beher sene tarafından zirâ'at ve öşri edâ olınagelür iken merkúm Mastafâ fazûlî zabt ve merkúm Zotri'ye ferâğ idüp gadr eylediği ve bilâ özr-i şer'î on sene geçmediği mahall-i nizâ‘ üzerinde me'mûrı hâzır oldığı hâlde ber nehc-i şer'î terâfa'da tebeyyün eylediği sûretde ol yirler me'mûrı ma'rifetiyle zü’l-yed olan merkúmdan mezbûre Ni`metî'ye alıvirilüp yedinde olan tapa senedi mûcebince zabt a tasarraf itdürilmek mavâfik-1 kãnûn idüği kalemi mezbûrdan tahrîr kılınmış olmağla siz ki matasarrıf-1 müşâr ve nâib vesâir mûmâ ileyhimsiz ma'rifetinüz ve ba tarafdan ta 'yîn kılınan sadr-1 a'zamam dâiresi hademesinden Râsim zîde kadrahû ma'rifet ve mübâşereti ile hasûs-1 mezbûrı şer'-i şerîfe ve bâlâda maharrer kãnûn-1 münîfe tatbîk iderek hasûs-1 mezbûr inhâ olındığı üzre oldığı ve bilâ özr-i şer‘î on [sene] geçmediği mahall-i nizâ‘ üzerinde me'mûrı hâzır oldığı hâlde ber nehc-i şer'-i terâfa'da tebeyyün eylediği sûretde ol yirler me'mûrı ma'rifetiyle zü'l-yed olan merkúmdan mezbûre Ni‘metî'ye alıvirilüp yedinde olan tapa senedi mûcebince zabt a tasarraf itdürilerek ihkãk-1 hakka mübâderet ve eger mahallinde ihkãk-1 hakk mümkin olmayapda müdde'a-i aleyhün der- 
edip öşür vergisini vermekte iken kocası Mustafa kanuna aykırı olarak müdahale edip Pendik Köyü'nden ve teba-i Devlet-i aliyyemden Zotri'ye adı geçen tarlayı kanunsuz olarak satmış, ferağ etmiş ve adı geçenin kendisini zarara uğrattı̆̆ını beyan etmiştir. Mübaşir tarafindan kanuna göre hareket edilmesi mümkün olmazsa adı geçenin İstanbul'a getirtilmesi babında emr-i şerifim gereği Divan-1 Hümayuna başvurulduğunda Nimeti'nin tapu ile mutasarrife olduğu anlaşılmıştır. Tasarruf hakkını da rızası ile kocası Mustafa'ya bırakmıştır. Ancak Mustafa buraları haksız yere Zotri'ye satmış olduğundan kanuni bir şekilde mi yoksa kanunsuz olarak mı satıldığının araştırılması gerekmektedir. Nimeti buraları zapt ve ziraat edip her sene öşür vergisini vermiş ise Mustafa'nın fuzuli yere özürsüz olarak 15 sene geçmediği halde Zotri'ye sattı̆̆ 1 anlaşılacaktır. Bu durumda buralar elindeki tapu senedi gereği Nimeti'ye tekrar iade edilmesi gerekir. Bu konuyu araştırmak için sadrazam, naip ve diğerleri tarafından sadrazam dairesi hademesinden Rasim görevlendirilmiştir. Yapılan incelemede haksız yere ve kanunsuz satıldığı anlaşıldığından buraların tekrar elindeki tapu gereğince Nimeti' ye verilerek zabt ve tasarruf ettirilerek karşı tarafın da mahkeme masraflarını karşılayacağı ile ilgili gerekli işlemleri hakkıyla yapmanız" olarak özetlenebilir.

25 numaralı 68 sayılı hüküm kaydı ${ }^{20}:$ " Fâtıma adlı kadın Şile Kazasına bağlı Karacaviran Köyü’ndeki mutasarrıfe olduğu tarlalarda ziraat yapıp öşür vergisini verirken, 1270 senesinde ölümü üzerine kızı Meryem'e karşılıksız olarak intikal etmiştir. O da vergi memuruna harçları vermiş iken amcasının oğlu olan Sakti(?) oğlu Hüseyin'in buraları haksız yere zapt edip yerine de Eyüp adlı kişiyi vekil tayin ettiği beyanıyla, Meryem Hatun tarafından gönderilen dilekçe üzerine inceleme yapılmıştır. Kanun gereği 1263 cemaziyelahir başından itibariyle ölenlerin tarlaları kızlarına da intikal etmektedir. Bundan dolayı Meryem'in annesi Fâtıma Hatun tapu ile mutasarrıfe iken yaşarken sahib-i arz aracılığı ile Sakti(?) oğlu Hüseyin'e ferağ edip kendisine bir senet vermiștir. Fatma Hatun, bu şekilde ziraat edilip vergilerini verirken 1270'de ölmüştür. Bunun üzerine kanun gereği Meryem'e bedelsiz olarak intikal etmiş olan tarlaları, amcasının oğlu Hüseyin'in fuzuli yere zapt etmiş olduğu anlaşılmıştır. Söz konusu yerlerin Meryem'e verilerek gerekli tedbirlerin alınması ve fuzuli müdahalelerin engellenmesi emr-i şerifim olduğundan siz ki kaymakam, naip ve diğer yöneticiler olarak kanuna göre hareket edesiniz. Hakkı olana hakkını yukarıda yazılı kanuna göre veresiniz. O

\footnotetext{
bâr-1 şevket-karâr-1 mülûkâneme ihzârı lâzım gelür ise keyfiyyetün îzâhen i'lâm ve iş‘ârına müsâra'at ve ba tarafdan ücreti mübâşiriyye ilâ âhirihî dikkat eylemenüz bâbında(1857).

${ }^{20}$ BOA 25/38/68 Ricâl-i Devlet-i aliyyemden Kocaili sancağı kãimmakãmı Cemîl Beğ dâme alüvvahûya ve Şile kazâs1 nâibine ve müdîr-i kazâ ve vücûh-1 memlekete hüküm: Fâtıma nâm hâtûnan Şile kazâsına tâbi‘ Karacavîrân karyesi toprağında vâkı' ma'mûlün bih tapa senediyle matasarrıfe oldığı ma'lûmetü'l-hadûd tarlalarını zabt ve beher sene tarafindan zirâ'at ve öşri me'mûrına edâ olınagelür iken iki yüz yetmiş senesinde müteveffiye oldakda ol yirler meccânen kızı yine karye-i mezbûre sekenelerinden Meryem nâm hâtûna intikãl idüp harc-1 intikãlini me'mûrına edâ itmek üzre iken yine karye-i mezbûre sâkinlerinden ammisi Sakti(?)oğlı Hüseyin dimeğle meşhûr kimesne ol yirleri hilâf-1 kãnûn fazûlî zabt idüp gadr eylediği ve tarafından oğlı Eyyûb nâm kimesneyi vekîl nasb itmiş oldığı beyânıyla kãnûn üzre amel olınmak bâbında emr-i şerîfüm sadûrı mezbûre Meryem Hâtûn tarafından ba def'a bâ arz-1 hâl istid‘â olınmış ve Dîvân-1 hümâyûnam kaleminden kãnûn ve maktezâsı saâl olındakda iki yüz altmış üç senesi Camâde'l-ûlâsı garresinden sonra müteveffiye olanlaran tarlaları meccânen ve mütesâviyen kızına intikãl eylemesi kãnûn olap münâza'an fîhâ olan tarla mezbûre Meryem'ün vâlidesi mezbûre Fâtıma Hâtûn bâ tapa matasarrıfe iken hâl-i hayâtında hakk-1 tasarrafını rızâsı ve sâhib-i arz ma'rifetiyle merkúm Sakti(?)oğlı Hüseyin'e ferâğ a tefvîz itmiş ve yedine ma'mûlün bih sened virilmiş ise zabt eylemesi hasbe'l-kãnûn yolında olap eğer böyle olmayabda fi'l-hakïka mezbûre Fâtıma ol tarlaya bâ tapa matasarrıfe olarak zabt ve beher sene tarafından zirâ‘'at ve öşri me‘mûrına edâ olınagelür iken iki yüz yetmiş senesinde fevt oldakda ol yirler hasbe'lkãnûn meccânen kızı mezbûre Meryem'e intikãl idüp harc-1 intikãlini me’mûrına edâ itmek üzre iken merkúm Hüseyin fazûlî zabt eylediği mahall-i nizâ' üzerinde me'mûrı hâzır oldığı hâlde vekîliyle hîn-i terâfa'da inde'ş-şer' ve'l-meclis tebeyyün eylediği sûretde vâlidesi yirleri mezbûre Meryem'e alıvirilüp ber mûceb-i nizâm tesviye olınmak içün emr-i şerîfüm i'tâsı iktizâ eylediği kalem-i mezbûrdan tahrîr kılınmış olmağla siz ki kãimmakãm ve nâib vesâir mûmâ ileyhimsiz hasûs-1 mezbûrı șer'-i șerîfe ve bâlâda maharrer kãnûn-1 münîfe tatbîk iderek ber vech-i hakkaniyyet ra'yet birle fi'l-hakïka merkúman ol yirleri fazûlî zabt eylemesi hilâf-1 kãnûn idüği mahall-i nizâ‘ üzerinde mezbûrı hâzır oldığı hâlde hîn-i terâfa'da inde'ş-şer' ve'l-meclis tebeyyün eylediği sûretde vâlidesi yirleri mezbûre Meryem'e alıvirilüp ber mûceb-i nizâm tesviye olınması hasûsına mübâderet hasûs-1 mezbûr ilâ âhirihî dikkat ve keyfiyyetün kaydı bâlâsına şerh virilmek üzre der-bâr-1 şevket-karâr-1 mülûkâneme inhâ ve iş'ârına müsâra'at eylemenüz bâbında(1861).
} 
yerlerin Meryem'e verilip daha sonra da bu konuyu kayıt altına alıp benim makamıma kararı ve kaydı gönderesiniz" şeklinde özetlenebilir.

\section{Sonuç}

Osmanlı Devleti'nde, Jennings (1975), Barkan (1993), Zarinebaf-Shahr (2000), Gerber (1980), Faroqhı (2000), Akyüz (2007), Gürhan (2017), Akyılmaz (2017), Baş (2006) gibi araştırmacılar tarafından arşiv belgelerinden yola çıkarak yapılmış olan diğer çalışmalarla uyumlu olarak, kadınların gerek yerel mahkemelerde gerek Divan-1 Hümayun'a başvurarak haklarını aradıkları bu çalışmada incelenen 19. yüzyıla ait İstanbul Ahkâm Defterleri'ndeki kayıtlardan da görülmüş̧ür.

Divan-1 Hümayun'a başvuru yoluyla hak arama yönteminin kullanımı ile ilgili olarak Divan1 Hümayun'un İstanbul'da olmasının sağladığı ulaşım avantajından dolayı diğer bölgelere oranla İstanbul için bu hakkın daha çok kullanılabildiği belirtilebilir. Arşiv belgelerinden yola çıkarak yapılan bu çalışmalarda da görüldüğü üzere şikâyet edilen kişi genellikle bir erkek olmuştur. Şikâyetlerin bir vekil aracılığı ile değil de bizzat kendilerince yapıldığı örnekler de yoğun olarak mevcuttur. Bu da kadınların haklarını kendilerinin de savunmak ve dile getirmek istedikleri yönünde bir tespit olarak değerlendirilebilir. Ayrıca ahkâm kayıtlarına yansıyan tüm anlaşmazlıkların çözümünde iddiaların araştırılması ve kanuna uygun hareket edilmesi gerektiği vurgulanmaktadır.

Tarımsal faaliyetlerle ilgili kadınlar tarafından yapılan başvuru nedenleri değerlendirildiğinde, bütün ahkâm kayıtlarında olduğu gibi hissedarların, akrabaların veya bölge sakinlerinden bir kimsenin haksız müdahalesinin engellenmesi amacıyla yapılan başvuruların en çok karşılaşılan başvuru nedeni olduğu görülmüștür. Bu gerekçe ile yapılan başvurular kadınların başvurularının yaklaşık \%72'sini oluşturmaktadır. Kadınların müracaat eden konumunda olduğu 202 ahkâm kaydının 77'si kendilerine ait olan tımar, mülk çiftlik, tarla ve arazilere, 22'si mera, yaylak, kışlak, otlak, çayıra, 31'i ise bağ, bahçe ve bostana müdahaleden kaynaklanmıştır. Müdahalen sonra en çok karşılaşılan sorunların ise daha çok mirasen intikal ile ilgili olduğu görülmektedir ki kadınlar tarafından yapılan başvuruların yaklaşık \%43'ünü oluşturmaktadır. Bu kayıtların içinde, miri toprağın, sazlık ve kamışlığın mirasen intikali" ile ilgili 60, "mülk, bağ, bahçe ve tarlanın mirasen intikali" ile ilgili ise 27 kayıt mevcuttur. Bunun yanı sıra tımar toprağın ferağ ve tefvizi (11 kayıt), fazla vergi talebi ve tahsili (5 kayıt), mültezimin vergi tahsiline müdahale (3 kayıt) ve vergi olarak toplanan mahsule müdahale ( 2 kayit) gibi nedenlerle başvurular da mevcuttur.

Tarımsal faaliyetlerle ilgili İstanbul Ahkâm Defterlerinde 1800-1875 y1llarını kapsayan döneme ait kayıtların yaklaşık \%15'ini kadınların yaptığı başvurular oluşturmuştur. Başvuru gerekçeleri açısından kadınların kendilerine ait olan alanlardan sırasıyla tımar, mülk çiftlik, tarla ve arazilere, mera, yaylak, kışlak, otlak, çayıra, bağ, bahçe ve bostana müdahale en çok karşılaşılan başvuru sebebidir. Tarımsal faaliyetler ile ilgili İstanbul Ahkâm Defterlerinde cinsiyet ayrımı olmaksızın en çok başvuru gerekçesi müdahalelerdir. Bunu yine yoğun olan mirasen intikal ile ilgili problemler takip etmiştir (K. Çeken, 2013: 386). İncelenen çalışamalarda kadınların kendilerine tanınan yasal hakları kullanırken karşılaştıkları engellere karşı yine yasalarca tanınan şikâyet etme haklarını kullanmak için mücadele ettikleri söylenebilir.

\section{Kaynakça}

Akyılmaz, G. (2017). "Osmanlı Devleti'nde Kadınların Mülkiyet Hakları ve Karşılaştıkları Hukuki Sorunlar”, TBB Dergisi Özel Sayl: 325-364.

Akyılmaz, S.G.(2007), “Osmanlı Miras Hukukunda Kadının Statüsü”, Gazi Üniversitesi Hukuk Fakültesi Dergisi C. XI, S.1-2. 
Akyüz, Julide. (2007), Osmanlı Kadınlarının Hukuksal Haklarını Kullanımı Hakkında Bazı Değerlendirmeler, Hacettepe Üniversitesi Türkiyat Araştırmaları (HÜTAD), Sayı 6, ss.7591.

Argıt, B.İ. (2005). “Osmanlı Hukuk Çalışmalarında Kadın”, Türkiye Araştırmaları Literatür Dergisi, III, 5, İstanbul: 575-621.

Aydın, M.(2015). “Osmanlı Divan Teşkilatı ve 1281-1296/1864-1879 Tarihli 19 Numaralı Erzurum Vilâyet Ahkâm Defterinin Tarihi Kıymeti”, Curr Res Soc Sci, I, 3: 69-83.

Barkan Ö. L. Edirne Askeri Kassamı'na Ait Tereke Defterleri(1545-1659), Belgeler, III/5-6, Türk Tarih Kurumu, Ankara Ankara 1993, s. 20.

Baş, E.(2006). Arşiv Belgelerinden Hareketle XVIII. Y. Y. Osmanlı Toplum Hayatında Kadın, Yayınlanmamış Yüksek Lisans Tezi, Marmara Üniversitesi Sosyal Bilimler Enstitüsü, İstanbul.

Başbakanlık Osmanlı Arşiv Rehberi. (2010). İstanbul: Başbakanlık Basımevi.

Can, S.(2008). "Osmanlı Mahkemelerinde Kadın”, Prof. Dr. Yavuz Ercan Armağanı, Turhan Kitabevi, Ankara: 197-223.

Ekinci, E.B.(2012). Osmanlı Hukuku; Adalet ve Mülk, İstanbul: Arı-Sanat Yayınları.

Faroqhı, Surarya.(2000). "Osmanlı Kadınları ve 18. Yüzyılda Adalet Arama Geleneği”, Modernleşmenin Eşiğinde Osmanlı Kadınları, (Ed) Madeline C.Zılfi, (Çev) Necmiye Alpay, Taih Vakfi Yurt Yayınları 111, İstanbul:7-26.

Gerber, Haim.(1980), "Social and Economic Position Of Women in an Ottoman City, Bursa 16001700", International Journal of Middle East Studies, Vol. 12, No. 3: 231-244 https://dx.doi.org/10.1017/S0020743800026295.

Gümrükçüoğlu, S.O. (2012) "Şikâyet Defterlerine Göre Osmanlı Teb'asının Şikâyetleri”, AUHFD, 61 (1): 175-206, https://dx.doi.org/10.1501/Hukfak_0000001654.

Gürhan, Veysel. "Kadınların Divan-1 Hümayun'a Şikâyet Haklarını Kullanmaları Üzerine Bazı Değerlendirmeler (Diyarbekir Eyaleti 1 Numaralı Ahkâm Defterine Gör", Tarih Okulu Dergisi (TOD Aralık 2017, Y11 10, Say1 XXXII: 323-347, https://dx.doi.org/10.14225/joh1149.

Jennings, Ronald.(1975), "Women in Early 17th Century Ottoman Judicial Records: The Sharia Court of Anatolian Kayseri", Journal of the Economic and Social History of the Orient, Vol. 18, No (1): 53-115, https://dx.doi.org/10.2307/3632221.

Özgişi, T.(2014). : "Osmanlı Adalet Sisteminde Bireysel Başvuru Hakkı”, Yalova Sosyal Bilimler Dergisi, IV, 8, Yalova: 52-66, https://dx.doi.org/10.17828/yasbed.21517.

Zarinebaf-Shahr, Fariba.(2000). "Osmanlı Kadınları ve 18. Yüzyılda Adalet Arama Geleneği”, Modernleşmenin Eşiğinde Osmanlı Kadınları, (Ed) Madeline C.Zılfı, (Çev) Necmiye Alpay, Taih Vakf1 Yurt Yayınları 111, Aralık 2000, İstanbul:241-250.

Kal'a, A. (1997). İstanbul Ahkam Defterleri: İstanbul Tartm Tarihi II (1757-1763), Yayın Haz. Kurulu: Ahmet Tabakoğlu v.dğr./and others, İstanbul: İstanbul Büyükşehir Belediyesi Kültür İşleri Daire Başkanlığ İ̀stanbul Araştırmaları Merkezi.

Kal'a, A. İstanbul Ahkam Defterleri: İstanbul Tarım Tarihi, 1805-1875, (Yayınlanmamış kitap), Yayın Haz. Kurulu: Ahmet Tabakoğlu v.dğr/and others, İstanbul. 
Kavak Çeken Ç. (2013), İstanbul Ahkam Defterleri Üzerinden 19.yüzyılda Osmanl Tarımının Ekonomik ve Hukuki Yönleriyle Değerlendirilmesi, (Yayınlanmamış Yüksek Lisans Tezi, Marmara Üniversitesi Sosyal Bilimler Enstitüsü, İstanbul.

Kenanoğlu, M. Macit. (2005), “Miri Arazi”, İslam Ansiklopedisi, 30. Cilt, İstanbul: 157-160.

Kenanoğlu, M. Macit.(2006), “Arazi Kanunnamesi ve Uygulaması”, Türk Hukuk Tarihi Araştıramaları, Sayı 1, İstanbul: 107-138.

Solak, İbrahim.(2006), Bozkır ve Çevresinden Konya Mahkemesine İntikal Eden Bazı Olaylar (17201750), Uluslararası Sempozyum Geçmişten Günümüze Bozkır, 991-1004.

Şimşek, Suat.(2011). Türk Hukukunda ve Avrupa İnsan Hakları Sözleşmesinde Mülkiyet Hakkı, Maliye Bakanlığı, Strateji Geliştirme Başkanlığı, Yayın No: 211/413, Ankara.

\section{ARŞIV BELGELERI}

BOA, , Bab-1 Asafi Divan-1 Hümayun Sicilleri İstanbul Ahkam Defterleri (A. DVNS. AHK. İS.d.) 18-19-20-21-22-23-24-25.

BOA, A. DVNS. AHK. İS. d. 18, s. 207, h. 411, 1815, (BOA 18/207/411).

BOA, A. DVNS. AHK. İS. d. 19, s. 39, h. 106, 1816 (BOA 19/39/106).

BOA, A. DVNS. AHK. İS. d. 19, s. 44, h. 119, 1816, (BOA 19/44/119).

BOA, A. DVNS. AHK. İS. d. 19, s. 65, h. 175, 1817, (BOA 19/65/175).

BOA, A. DVNS. AHK. İS. d. 20, s.22, h. 64, 1820, (BOA 20/22/64).

BOA, A. DVNS. AHK. İS. d. 20, s. 92, h. 265, 1823, (BOA 20/92/265).

BOA, A. DVNS. AHK. İs. d. 20, s. 156, h. 418, 1825, (BOA 20/156/418).

BOA, A. DVNS. AHK. İS. d. 20, s. 245, h. 597, 1830, (BOA 20/245/597).

BOA, A. DVNS. AHK. İs. d. 21, s. 27, h. 70, 1833, (BOA 21/27/70).

BOA, A. DVNS. AHK. İS. d. 22, s. 38, h. 71, 1843, (BOA 22/38/71).

BOA, A. DVNS. AHK. İS. d. 24, s. 72, h. 156, 1857, (BOA 24/72/156).

BOA, A. DVNS. AHK. İS. d. 24, s. 101, h. 227, 1858, (BOA 24/101/227).

BOA, A. DVNS. AHK. İS. d. 25, s. 38, h. 68, 1861, (BOA 25/38/68). 